UDK 811.163.42“15“

Izvorni znanstveni rad

Rukopis primljen 23. XII. 2019.

Prihvaćen za tisak 18. III. 2020. https://doi.org/10.31724/rihjj.46.1.12

\author{
Andrea Radošević \\ Staroslavenski institut \\ Demetrova 11, HR-10000 Zagreb \\ aradosevic@stin.hr
}

\title{
VITAE PATRUM U EGZEMPLIMA GLAGOLJSKIH KNJIGA DISIPULA IZ 16. STOLJEĆA
}

U radu se analiziraju tekstovi iz Vitae Patrum koji se u obliku egzempla pojavljuju u glagoljskim Disipulima iz 16. st. Istražuje se na koji su način anegdote monaške tematike prilagođene dominikanskoj duhovnosti unutar koje je nastala latinska zbirka propovijedi Sermones Discipuli. Također se uspoređuje odnos prema monaškim motivima u četirima prijepisima Disipula. S obzirom na to da su u dosadašnjim medievističkim studijama objavljeni uglavnom izvori predložaka egzempla iz Heroltova Egzemplara, istraživanju glagoljskih Disipula prethodilo je utvrđivanje predložaka četiriju latinskih egzempla koji se pojavljuju u dvama Heroltovim propovjednim ciklusima: sermones de tempore i sermones de sanctis. Otkriveno je kako je riječ o trima egzemplima nastalim prema anegdotama iz Verba seniorum te jednoj anegdoti Ivana Egipatskoga koja je zapisana u tekstovima Historia Lausiaca i Historia monachorum. Iz Heroltova Egzemplara u Disipule je dospjela jedna anegdota iz Verba seniorum, čija tri izvora u svojoj raspravi detaljno navodi Hermand (1995).

U radu se opisuju književnopovijesne, stilske i jezične značajke glagoljskih egzempla. Naime, upravo se proučavanjem zbirkā propovijedi, koje najčešće sadržavaju više kompiliranih monaških anegdota, može rasvijetliti hrvatski srednjovjekovni korpus Vitae Patrum. Cilj je istraživanja upotpuniti sliku recepcije Vitae Patrum u hrvatskoj srednjovjekovnoj književnosti te pridonijeti poznavanju uporabe jezika u kratkim narativnim tekstovima 16. st. Na kraju rada prvi se put objavljuje transliteracija svih pet egzempla. Svaki egzempl donosi se u nekoliko prijepisa (ne u svima), pri čemu su obuhvaćena sva četiri rukopisa Disipula. 


\section{Uvod}

U studiji o hrvatskom srednjovjekovnom legendariju Ivanka Petrović govori kako „osim pasija, hagiografija, Marijinih mirakula i jedinstvenih tematskih hagiografsko-legendarnih ciklusa, u hrvatskoj legendardnoj književnosti postoji više politematskih legendarnih skupina” (Petrović 1990: 190). Kao najjednostavniji oblik takve legendarne fabularne proze izdvaja se egzempl ${ }^{1}-$ kratki $^{2}$ narativni tekst jednostavna stila kojim se prenosi pouka te koji gotovo redovito sudjeluje u izgradnji argumentacijskog postupka propovjedničke proze (Petrović 1990: 190-191). U ovom kontekstu govorimo samo o egzemplima² koji su oblikovani prema znatno starijim hagiografsko-legendarnim predlošcima, točnije prema zbirci Vitae Patrum, koja je snažno obilježila duhovnost europskoga srednjovjekovlja, ali i kasnijih razdoblja. ${ }^{3}$ Većina ih je u hrvatsku književnost dospjela s prijevodima raznih djela namijenjenih između ostalog pripremanju propovijedi. Nastojeći barem dijelom upotpuniti sliku po raznim rukopisima razasutoga hrvatskog srednjovjekovnog legendarnog korpusa (Petrović 1990: 192), u ovom ću radu istražiti recepciju Vitae Patrum u egzemplima četiriju glagoljskih rukopisa iz 16. stoljeća u kojima je sačuvan hrvatski prijevod vrlo popularne latinske zbirke propovijedi Sermones Discipuli. Kao uvod u analizu egzempla slijedi kratak povijesni pregled zbirke Vitae Patrum, opis njezina položaja unutar dominikanske duhovnosti te pregled stanja istraženosti njezine recepcije u hrvatskoj medievistici.

\section{Vitae Patrum i dominikanska duhovnost}

Pitanje korpusa Vitae Patrum do danas nije u potpunosti riješeno. U početku taj se naziv odnosio samo na životopise prvih egipatskih anahoreta i monaha, no s vremenom njime bivaju obuhvaćeni razni drugi tekstovi pustinjačke tematike (Petrović 1984: 187). Smatra se kako Vitae Patrum nikad nisu bile jedno cjelovito djelo ni organizirana zbirka, kako bi se moglo zaključiti na temelju tekstova

Welter 1973, Bremond, Le Goff i Schmitt 1996: 66. U glagoljskoj književnosti najčešće se pojavljuju u zbirkama propovijedi kao tzv. propovjedni egzempli (Zaradija Kiš 2012: 116-117).

2 Izvore u sastavljanju egzempla srednjovjekovni su kompilatori nalazili u raznim djelima: Vitae Patrum, životopisima svetaca, raznim kronikama i sl.

3 Philippart 1974: 365, Delcorno 1991: 207. 
koji su prema 2. izdanju zbirke Heriberta Rosweydea iz 1628. objavljeni u 73. i 74. knjizi čuvene edicije Patrologia latina (Di Sciacca 2014: 130). U širem sastavu, koji odgovara Rosweydeovoj zbirci, Vitae Patrum obuhvaćaju brojne druge skupine poučnih tekstova, zbirke anegdota i sentencija vezane uz pustinjački život (verba, sententiae, apophthegmata, dicta i dr.) (Philippart 1974: 353).

U 13. stoljeću Vitae Patrum dobivaju brojne čitatelje među pripadnicima dominikanskoga i franjevačkoga reda. Nastojeći oživjeti apostolske ideale ranoga kršćanstva, dominikanci su osobito voljeli u svojim narativima i hagiografijama isticati primjere pustinjskih otaca koje su smatrali prethodnicima zapadne monaške tradicije (Delarue 2018: 126). Po uzoru na opise pustinjskih otaca oblikovali su životopise istaknutih pojedinaca svojega reda kao i svetačke vitae (Delcorno 1991: 199). Njihov je utjecaj na oblikovanje dominikanske duhovnosti golem (Boureau 1987, Delcorno 1991: 190). Po uzoru na Vitae Patrum Gérard de Frachet sastavio je Vitas fratrum - zbirku dominikanskih facta i dicta, odnosno zbirku suvremenih pustinjskih otaca (Jotischky 2002: 284). U svoju Zlatnu legendu Jakov iz Varrazea (Jacobus de Voragine) uvrstio je poglavlja o Makariju, Antunu Pustinjaku, Mariji Egipćanki, Hilarionu, opatu Mojsiju, Arseniju i Agatonu, dok je Vincent iz Beauvaisa u svojemu čuvenom Povijesnom zrcalu (Speculum historiale) opisujući monaške vrline unosio tekstove o Mojsiju Etiopskom, Makariju Egipatskom i dr. (Jotischky 2002: 234-235). U svim tim djelima, a osobito u Povijesnom zrcalu i Zlatnoj legendi, više se nego jasno iščitava dominikanska namjera prikazivanja duhovnoga kontinuiteta između monaške prakse ranoga kršćanstva i novih crkvenih redova 13. stoljeća.

Vitae Patrum smatrane su gotovo neiscrpnim izvorom građe za kojom su posezali autori raznih traktata, suma, komentara, propovijedi, zbirka egzempla i sl. Nalazimo ih u Traktatu o vrlinama i grijesima (Summa virtutum ac vitiroum) Guillelma Peralda, Teološkoj sumi (Summa theologiae) sv. Tome Akvinskoga, Povijesnom zrcalu (Speculum historiale) Vincenta iz Beauvaisa i dr. Gotovo je nemoguće pronaći zbirku egzempla toga vremena u kojoj barem jedan tekst nije nastao po uzoru na Vitae Patrum: Liber de dono timoris Humberta iz Romansa, Bonum universale de apibus Tome iz Cantimpréa, Alphabetum narrationum Arnolda iz Liègea i dr. ${ }^{4}$

4 Vidi Crane 1890, Jotischky 2002: 284. 
Među tekstovima Vitae Patrum osobitu su popularnost uživala Verba seniorum ${ }^{5}$ kao zbirka kratkih tekstova povezanih s asketskim životom pustinjskih otaca u Egiptu i na Bliskom istoku. Ona sadržavaju nekoliko stotina apoftegmatskih tekstova (verba, sententia, dicta): od instrukcija i pouka iznesenih u svega jednoj rečenici pa sve do duljih narativa u kojima se govori o osnovnim vrlinama monaštva kao što su poniznost, milosrđe, poslušnost (Winfried 2014: 183). Korpusu Vitae Patrum ovaj se tekst počinje dodavati već u 9. st. Zna se da su ga s grčkoga originala na latinski jezik u 6 . stoljeću preveli rimski đakon Pelagije, njegov podđakon Ivan i đakon Pashazije, ${ }^{6}$ no nastanak i rana transmisija djela još nisu dovoljno istraženi. ${ }^{7}$ Verba seniorum ${ }^{8}$ objavljena su u PL 73 u nekoliko knjiga, po uzoru na već spomenutu Rosweydeovu zbirku: Liber V i Liber VI obuhvaćaju Adhortationes Sanctorum Patrum rimskoga đakona Pelagija ${ }^{9}$ i rimskoga podđakona Ivana, ${ }^{10}$ Liber VII odnosi se na tekst Liber geronticon đakona Pashazija, ${ }^{11}$ a Liber III sadržava Pseudo-Rufinovu ${ }^{12}$ zbirku anegdota. ${ }^{13}$

„Temeljni je svjetonazor u Verba seniorum potpuna askeza - ustezanje i odricanje od svega ovozemaljskoga, od svih tjelesnih dobara, od jela i pića, suvišne odjeće, tjelesne ljubavi, smijeha. Nepomućena vjera, molitva, čitanje Biblije, osama, šutnja, plač, post, težak rad okviri su života egipatskih pustinjaka i redovnika. Isposnička borba protiv napasti. Apsolutna tjelesna i duhovna čistoća. To je odraz ranosrednjovjekovne duhovnosti koja je bila uzorom kroz čitav sred-

\footnotetext{
Postoji više od stotinu srednjovjekovnih rukopisa koji su sadržavali cjelovitu zbirku Verba seniorum (Winfried 2014: 184).

6 Georges Garnefelt prvi je iznio pretpostavku kako je Pelagije zapravo papa Pelagije I. (556. - 561.), a njegov podđakon budući papa Ivan III. (561. - 574.) (Philippart 1974: 354, Petrović 1984: 187).

7 O utvrđivanju grčkoga predloška, na čemu su radili W. Bousset, J.-C. Guy, J.-M. Sauget, A. Wilmart i drugi vidi u Philippart 1974.

8 Više o problematici sastava Verba seniorum, raznim izdanjima i pitanjima autorstva pojedinih knjiga tijekom povijesti vidi u Philippart 1995, Bertrand 2006.

$9 \quad$ Nazive kratica (Joan., Pasch., Pel. i Ruf.) i cjelovite podatke o knjigama koje čine Verba seniorum u bilješkama 9., 10., 11. i 12. navodim prema Malić 1996: 66 i Malić 1997: 12. De vitis patrum liber quintus, sive Verba seniorum, auctore graeco incerto, interprete Pelagio S. R. E. diacono, PL 73, col. 851-992 (kratica Pel.).

${ }_{10}$ De vitis patrum liber sextus, sive Verba seniorum graeco incerto. Interpete Joanne S. R. E. subdiacono, PL 73, col. 991-1024 (kratica Joan.).

${ }_{11}$ De vitis patrum liber septimus, sive Verba seniorum, auctore graeco incerto, interprete Paschasio $\mathrm{S}$. R. E. diacono, PL 73, col. 1025-1062 (kratica Pasch.).

12 De vitis patrum liber tertius, sive Verba seniorum, auctore probabili Ruffino Aquileiensi presbytero, PL 73, col. 739-814 (kratica Ruf.).

13 Bertrand (2006: 182) navodi kako Pseudo-Rufinova zbirka sadržava kompilaciju tekstova iz Commonitiones sanctorum patrum, Pashazijeva teksta Liber geronticon i Jeronimova pisma.
} 
nji vijek i koja je bila razlogom da su razne verzije bile raširene i vrlo popularne" (Malić 1997: 18-19).

Ono što je svakako pridonosilo učestaloj uporabi tekstova iz Vitae Patrum u raznim oblicima pastoralnih aktivnosti odnosi se na njihovu dvostruku, egzemplarnu i autoritativnu, funkcionalnost (Hermand 1995: 7-8, Jotischky 2002: 284). ${ }^{14}$ Naime, upravo zbog pozivanja na kontinuitet monaške duhovnosti, isticanje kako je tekst zapisan u vrijeme svetih otaca imalo je snažnu autoritativnu vrijednost. Interpretacija propovjednika pritom je bila usmjerena na ispovjedničko-pokorničku poruku pustinjaštva, iako najčešće izostaju prikazi teških odricanja pustinjaka i praksi askeze (Delcorno 1991: 200). Anegdote iz pustinjačkoga života smatrane su vrelom kršćanske mudrosti te su bile omiljene u opisivanju borbe s iskušenjima i strastima (osobito sotonom), zatim u skretanju pozornosti na svakodnevna suočavanja s raznim opasnostima, u prikazivanju obraćenja, razmišljanja o smrti i dr. (Boureau 1987: 83, Greer 1989: 100).

Osim Verba seniorum još su dvije zbirke iz Vitae patrum uživale popularnost te su snažno utjecale na kasniju religijsku književnost, primjerice na čuvene Dijaloge Grgura Velikoga (Harmless 2004: 275-276, 291). To su Historia monachorum koja se nekad pripisivala Rufinu Akvilejskomu ${ }^{15}$ i Paladijeva antologija anegdota i mirakula Historia Lausiaca, dva teksta koja su se u prošlosti često zajedno prepisivala u iste knjige te koja se sadržajno djelomice preklapaju. Historia monachorum iznimno je vrijedan izvor za povijest ranoga egipatskog monaštva (Sheridan 2015: 124). U tom se tekstu pripovijeda o sedam kršćanskih monaha koji na kraju 4. stoljeća na putovanju od Jeruzalema do Egipta susreću više pustinjskih otaca. Za vrijeme tih susreta oni usvajaju neka njihova učenja te svjedoče raznim čudesima (čudotvornim izlječenjima, predviđanjima i sl). Djelo Historia Lausiaca nastalo je kao sjećanje na godine provedene u Egiptu tada već starijega monaha i biskupa Paladija (oko 363. - oko 431.). Riječ je o antologiji anegdota, kratkih moralnih priča ne samo raznih pustinjaka s kojima se Paladije susreo nego i brojnih muškaraca i žena posvećena života o kojima je slušao za

\footnotetext{
${ }_{14}$ Naime, unošenje narativnih egzemplarnih tekstova (exempla) jedan je od triju temeljnih načina argumentiranja u moralno-didaktičnim tekstovima, uz pozivanje na biblijske i patrističke citate (auctoritates) te nabrajanje dokaza (rationes) (Bremond, Le Goff i Schmitt 1996: 30-31).

15 Stajalište o njegovu autorstvu dugo se temeljilo na navodu iz Jeronimova 133. pisma. Danas se smatra kako je Rufin Akvilejski početkom 5. stoljeća izvorni grčki tekst preveo na latinski (Butler 1898, Sheridan 2015: 124).
} 
vrijeme svojega boravka u egipatskoj pustinji (Harmless 2004: 291). Djelo je brzo postalo popularno te je prevedeno na latinski, sirijski, armenski, koptski, etiopski i arapski (Harmless 2004: 275-276).

\section{Vitae Patrum u hrvatskoj književnosti}

Vitae Patrum, smatra Ivanka Petrović (2005: 288), jedan su od najčvršćih dokaza rane ukorijenjenosti hrvatske vernakularne književnosti u tradiciju latinskoga srednjovjekovlja. U radu posvećenu Guyju Philippartu, istaknutomu belgijskom medievistu i hagiografu, I. Petrović objavila je pregled recepcije Vitae Patrum u hrvatskoj srednjovjekovnoj književnosti i rekla kako ona poznaje hagiografske legende iz užega sastava Vitae Patrum, zatim latinske legende posvećene istaknutim pustinjacima, tekstove iz Apophthegmata Patrum i dr. (Petrović 2005).

Najpoznatiji, najdulji i najpotpuniji hrvatski tekst iz širega korpusa Vitae Patrum svakako su Žića svetih otaca, latinični rukopis s kraja 14. st. nastao na sjevernodalmatinskom području, ${ }^{16}$ a koji sadržava djelomičan prijevod Verba seniorum. Dragica Malić opisuje ih kao „prvu poznatu hrvatsku knjigu pripovjedačke proze monotematskoga sadržaja" koja je ujedno jedan od najznačajnih spomenika hrvatske srednjovjekovne književnosti (Malić 1997: 5-6). Žića se sastoje od dvaju dijelova, tj. prijepisa dvaju starijih predložaka koji su se u velikoj mjeri podudarali i u sadržaju. Prvi je dio kompilacija prvih deset knjiga Pelagija, dok drugi dio sadržava izbor knjiga Verba seniorum, no većinom ipak Pelagijeve tekstove (Petrović 2005: 304-305). Na temelju nekih prepisivačkih pogrešaka postoje pretpostavke o postojanju glagoljičnoga prijepisa nakon kojega je nastao latinični prijepis (Malić 1997: 14). Pretpostavlja se da su služila za potrebe redovničke lektire te kao pomagalo u sastavljanju propovijedi (Malić 1997: 17, 29).

Manja skupina pustinjačkih tema nalazi se u Dubrovačkom legendariju iz 17. stoljeća, nastalom prema starijem predlošku koji je preveden s talijanskoga jezika: Legenda o sv. Eufrosini, Legenda o Mariji grešnici, Legenda o sv. Pelagiji, Legenda o sv. Mariji Egipćanki te Legenda o Barlaamu i Jozafatu. Više hagiografsko-legendarnih tekstova zapisano je u glagoljičnim rukopisima na16 Vinko Premuda, Stjepan Ivšić i Dragica Malić razilaze se u tumačenju ukupnoga broja članaka u Žićima.
Vidi Malić 1997, Petrović 2005. 
stalim između 14. i 17. stoljeća: Život sv. Antuna Pustinjaka, ${ }^{17}$ Život sv. Pavla Pustinjaka, ${ }^{18}$ Translacija sv. Pavla Pustinjaka, ${ }^{19}$ Život sv. Hilarija,${ }^{20}$ Legenda o sv. Mariji Egipćanki ${ }^{21}$ (Petrović 2005: 291). Apophthegmata Patrum pojavljuju se unutar životopisa pustinjaka, kao egzempli u zbornicima i zbirkama propovijedi, unutar apokalipsa i dr. Tako anegdotu o Makariju i lubanji osim u Žićima svetih otaca nalazimo i u Grškovićevu zborniku iz 16. st., a anegdotu o vrtlaru koji je svu zaradu dijelio siromašnima u Petrisovu zborniku iz 1468. (Malić 1997: 18). U Ljubljanskom zborniku verzija anegdote o sv. Makariju i lubanji prepisana je zajedno s Pavlovom apokalipsom. Naime, Dürrigl (2010: 3) utvrdila je kako je pisar ,iz legende o sv. Makariju uzeo dijelove koji mu trebaju, a odbacio narativni višak i dijalog Makarija i anđela, pa je tako napravio teološki sastav, a ne narativni tekst”. Istaknimo kako osim Dubrovačkoga legendarija i Žića svetih otaca zbirke propovijedi čuvaju najveći broj tekstova iz Vitae Patrum. U senjskom Korizmenjaku, hrvatskom prijevodu korizmenih propovijedi talijanskoga franjevca Roberta Caracciola, čak je nekoliko egzempla nastalo po uzoru na Vitae Patrum: Sv. Makarij razgovara s glavom jednoga poganskoga popa, Drvo posluha i dr. (Zaradija Kiš 2008).

O korpusu Vitae Patrum u hrvatskoj su medievistici pisali Stjepan Ivšić (1939), Vinko Premuda (1939), Eduard Hercigonja (1975), Dragica Malić (1987, 1988, 1989, 1990, 1991, 1992, 1992-1993, 1993, 1996, 1997), ${ }^{22}$ Ivanka Petrović (1984, 1990, 2005), Vesna Badurina-Stipčević (1992-1993; 2004; 2008; 2011), Antonija Zaradija-Kiš (2008) i Marija-Ana Dürrigl (2010).

\footnotetext{
$17 \quad$ Badurina-Stipčević 2011.

18 Badurina-Stipčević 1992-1993.

19 Badurina-Stipčević 2008.

20 Badurina-Stipčević 2004.

21 Petrović 1972, Tatarin 2003.

22 Studije D. Malić: Slogotvorniril u starohrvatskom latiničkom rukopisu, Žića sv. otaca“(1987), Porijeklo i značenje riječi eselesse iz „Žića sv. otaca” (1988), Grafija i pravopis hrvatskog latiničnog rukopisa 14. stoljeća „Žića sv. otaca” (1989), Refleksi jata u „Žićima svetih otaca” (1990a), Tragovi glagoljičke tradicije u starohrvatskom latiničkom rukopisu „Žića svetih otaca” (1990b), Samoglasničke pojave u „Žićima svetih otaca” (1991), Kompjutorska obrada starohrvatskog latiničnog rukopisa 14. stoljeća „Žića sv. otaca” (1992), Izricanje budućnosti u „Žićima svetih otaca” (1992-1993), Konsonantizam u ,Žićima svetih otaca” (1993) objavljene su 1997. u Matičinu izdanju Žića svetih otaca: hrvatska srednjovjekovna proza.
} 


\section{Vitae Patrum u glagoljskim Disipulima}

Više tekstova iz zbirke Vitae Patrum u hrvatsku glagoljsku književnost dospjelo je s prijevodom popularne latinske zbirke propovijedi Sermones Discipuli de tempore et de sanctis cum Promptuario exemplorum et de miraculis Beatae Mariae Virginis njemačkoga dominikanca Johannesa Herolta $(\dagger 1468.){ }^{23}$ Hrvatski prijevod sačuvan je u četirima prijepisima: Disipulu $A$ iz sredine 16. st., Disipulu $B$ iz 1558., Disipulu C iz 1541. i Disipulu D iz 1600. godine. ${ }^{24}$ Pop Mihovil, plovan belgradski (u Vinodolu), za kojeg se pretpostavlja da je bio i prevoditelj latinskoga djela, pisao je Disipule A, B i C (Petrović 1977: 154). Ivan Brozović iz Selaca (Bribir), pisar najmlađega Disipula $D$, osuvremenio je jezik prijevoda i pojednostavnio grafijska rješenja.

Johannes Herolt bio je propovjednik izrazito stroga stava koji se posebno obrušavao na tjelesne grijehe, a upravo bi to mogao biti jedan od razloga njegova čestog posezanja za egzemplima iz Vitae Patrum. Naime, jedan od njegovih proučavatelja, J. Dahmus (Dahmus 1986: 124), smatra kako Heroltova obrana asketskih vrijednosti usko povezuje njegov opus s monaškim tekstovima. U egzemplima, kao i inače u svojoj zbirci propovijedi, Herolt napada ugodan način života, lijepu i skupu odjeću, mekanu postelju promičući asketizam kao pravi primjer ispravna kršćanskog života. Kao i drugi dominikanci toga vremena Herolt je posezao za monaškim egzemplima prilagođavajući široj publici razne teme drevnih pustinjaka (strpljivost, poniznost, iskušenje, odricanje), i to uglavnom prema načelu ad usum laicorum (Delcorno 1991: 201). Monaško načelo stabilitas loci, tj. isticanje potrebe da redovnik ostane na jednom mjestu (Malić 1997: 20), u dominikanskom kontekstu označava postizanje unutarnje stabilnosti koja se očituje u ustrajnom odolijevanju iskušenjima, izbjegavanju grijeha, oplemenjivanju duše te ispitivanju granica poslušnosti i strpljivosti.

Tekstove iz različitih dijelova Vitae Patrum Herolt je najčešće posredno unosio iz raznih srednjovjekovnih kompilacija (Hermand 1995: 13). Uglavnom je egzempl započinjao navodeći kako se nalazi u zbirci Vitae patrum (Haec in Vitis Patrum, Legitur in Vitis Patrum), a samo je katkada isticao točan broj knjige

\footnotetext{
23 Johannes Herolt (†1468.) veći dio života proveo je u Nürnbergu kao ispovjednik sestara sv. Katarine. Bio je prior tamošnjega dominikanskog samostana (od 1438.), a od 1451. generalni vikar samostana sv. Katarine. Više v. u Dahmus 1986, prema Radošević 2016a.

24 Više o Disipulima vidi u Štefanić 1960, Štefanić 1969, Petrović 1977, Radošević 2016a.
} 
ili poglavlja. Najčešće je ipak posezao za tekstovima iz Verba seniorum, a osobito je volio unositi anegdote o ocima Makariju ${ }^{25}$, Poemenu ${ }^{26}$, Sizoju i dr. Iako je većina egzempla unesena iz Verba seniorum, u Heroltovu latinskom djelu nalazimo anegdote i iz drugih dijelova Vitae patrum (Hermand 1995: 13). O tome piše Hermand navodeći izvore onoga dijela zbirke egzempla Promptuarium Exemplorum (tzv. Egzemplara) u kojem je Herolt posezao za raznim tekstovima iz korpusa Vita Patrum. Hermand (1995: 37-48) tako za svaki egzempl iz Egzemplara iscrpno navodi sve izvore Vitae Patrum u kojima se pojedini tekst pojavljuje. Ipak, njegova studija usmjerena je isključivo na Heroltov Egzemplar, ali ne i na egzemple koji se pojavljuju unutar njegove zbirke nedjeljnih i svetačkih propovijedi. U ovom smo radu stoga prvo istražili tekstove iz Vitae patrum koji se pojavljuju u njegovim sermones de tempore i sermones de sanctis te smo potom utvrdili njihove predloške. Rezultate tih istraživanja objavljujemo u uvodima transliteriranih egzempla u 6. poglavlju ovoga rada.

Utvrđeno je kako u glagoljskim Disipulima uz četiri egzempla unesena iz Verba seniorum koje nalazimo u Pelagijevim, Pashazijevim i Pseduo-Rufinovim knjigama nalazimo i jedan egzempl ${ }^{27}$ koji se temelji na priči Ivana Egipatskoga ${ }^{28}$, a koja je zapisana u Historia monachorum (HM), djelu koje je s grčkoga na latinski preveo Rufin Akvilejski, te u Paladijevoj antologiji anegdota i mirakula Historia Lausiaca (HL). Naime, u odnosu na latinsku zbirku glagoljski Disipuli sadržavaju znatno manje egzempla iz Vita Patrum. Poznato je kako hrvatski prijevod u izboru sadržava nešto više od trećine latinske zbirke, pri čemu je

\footnotetext{
25 Riječ je o Makariju Egipatskom koji se još zvao i Makarije Veliki kako bi ga se razlikovalo od Makarija Aleksandrijskog. Bio je učenik sv. Antuna Pustinjaka koji je oko 330. godine osnovao monašku zajednicu. Njegovi su sljedbenici bili poznati pustinjaci: Sizoje, svećenik Izidor, Arsenije, Poemen i drugi. Jedna je od istaknutih figura koptske tradicije i jedna od najčešćih osoba u tekstu Apophthegmata Patrum o čijem životu postoje brojne legende (Harmless 2004: 194-196).

26 Otac Poemen (Pastir), uz oca Makarija, jedan je od istaknutih protagonista Apophthegmata Patrum (Harmless 2004: 206).

27 Riječ je o egzemplu o vragu koji u obliku žene napastuje redovnika (Vrag zavodi pustinjaka u kipu lijepe žene), inače jednoj od anegdota opata Ivana Egipatskoga (Narratio abbatis Joannis de eo qui lapsus est) koja se pojavljuje u Historia monachorum i u Historia Lausiaca (Harmless 2004: 275-276, 291). Njegove anegdote karakterizira izrazito strog odnos prema ženama. U njima nalazimo ponajprije imaginarne posjete žena redovnicima, tj. ili je riječ o demonima prerušenima u žensko obličje ili o susretima koji se odvijaju u snovima.

${ }_{28}$ O ovom se proroku i čudotvorcu koji je poznat i kao Ivan Pustinjak i Ivan Lycopolis, a koji je promicao poniznost i askezu, danas ne zna mnogo. Sebastien Lenain de Tillemont, kako navodi Sheridan (2015: 123), upravo Ivana Egipatskoga smatra najpoznatijim i najvećim pustinjskim svetcem, odmah nakon sv. Antuna Opata, o kojem su pisali sv. Augustin, Jeronim, Ivan Kasijan i dr. Mirakuli i priče koje je pripovijedao svojim posjetiteljima čine prvo poglavlje zbirke Povijest monaštva (Historia monachorum).
} 
najviše zastupljen njezin propovjedni dio, dok egzemple i Marijine mirakule iz Heroltovih dviju zasebnih zbirki nalazimo u znatno manjem broju od onoga koji je nudilo njegovo djelo. S obzirom na to da je Heroltova zbirka propovijedi samo dijelom prevedena te da izostaje prijevod njegova Egzemplara kao zasebne zbirke egzempla (izuzev nekoliko egzempla unesenih u više propovijedi), u hrvatsku književnost nije dospio velik broj legendi koje je taj autor preuzeo iz Vitae Patrum. Razgovor Makarija i đavla jedan je od rijetkih egzempla iz Egzemplara koji se pojavljuje u glagoljskim Disipulima, a koji je potekao iz Vitae Patrum. No untaoč tome što u Disipulima nalazimo svega pet egzempla poteklih iz Vitae $\mathrm{Pa}$ trum, četiri iz Verba seniorum (Ruf., Pasch., Pel.) te jedan egzempl Ivana Egipatskog (HM, HL), u njima su okupljene važne pustinjačke teme, a kao protagonisti pojavljuju se dva čuvena pustinjska oca, Makarije i Poemen (Pastir).

Ono što obilježuje sva četiri prijepisa kontrakcija je različitih dijelova egzempla. ${ }^{29}$ Rijetke primjere skromne amplifikacije ${ }^{30}$ nalazimo uglavnom u obliku stilističkih proširenja te vrlo rijetkih dodanih teoloških tumačenja. Iako je većina kontrakcija i sažimanja odraz ekonomizacije izraza i naglašavanja didaktičnosti egzempla, ${ }^{31}$ ono je također posljedica prilagođavanja monaškoga narativa kontekstu kasnoga srednjovjekovlja.

Dulja kontrahiranja latinskoga teksta provode se kraćenjem opisa, sažimanjem dijaloga, apsolviranjem uzastopnih zbivanja jednim aktom ${ }^{32}$ i sl. Tako je primjerice istovjetan odgovor koji u latinskom predlošku prvo dêval iznosi poganskom popu, a on ga potom prenosi fratru, sintetiziran u jednu rečenicu, pri čemu je sam sadržaj odgovora kontrahiran uporabom pokazne zamjenice (to, tomu): Od'govori nemu dêval': „Ako zatai b(og)a s'voga i h(rsten'e) $i$ da oce van' iz reda poiti, dai mu $\hat{\text {. } . " ~ I ~ t o ~ e ~ p o p ' ~ p o v i d a l ~ f r a t r u, ~} i$ tudie e fratar pris'tal' $k$ tomu (A, 3c) prema lat. Respondens daemon, dixit: „Si negat Deum suum, et baptismum, et propositum monachi, interroga eum." Et veniens sacerdos dixit ei: „Nega Deum tuum, et baptismum, et propositum monachi, et dabo tibi filiam meam.” Ille vero consensit. ${ }^{33}$ Više je primjera sažimanja dijaloga kontrahiranjem

\footnotetext{
29 „Gotovo isključivo okretanje prema didaktičnosti, i to sažimanjem elemenata pripovjednog teksta, jedna je od najprepoznatljivijih značajka egzempla u glagoljskim Disipulima." (Radošević 2019: 23).

30 Zlatar 2002: 52-53.

31 Petrović (1977: 173-180) smatra kako su prepričavanja dijaloga uz česta kontrahiranja pojedinih dijelova teksta posljedica dominantnoga propovjednog diskursa Disipula.

32 Novaković 1986: 9.

33 Herolt 1603: 7.
} 
dvaju odgovora i pitanja u jedan dulji odgovor: I prišal' e drugi i pok'lonil mu se e gov(o)r(e)ci: ,,Bil' sam' v' mori.”(A, 76a) prema lat. Et ecce alius venit et adoravit eum. Et ab eo interrogatus: „Unde veniret?” Respondit: „Fui in mari”. ${ }^{4}$ Monahov trotjedni post u Disipulu $B$ apsolviran je samo jednom rečenicom u kojoj su unosom tuđice divicion kontrahirani postupci posta, pokore i molitve iz latinskoga predloška: I kada fratar pos'ti rečene $v(=3)$ n(e)d(e)le s velikim' divicionom' reče mu s'tarac' (A, 3d).

Za razliku od nekih drugih srednjovjekovnih tekstova u ovim egzemplima ne samo da nema uporabe dvaju glagola govorenja ${ }^{35}$ (Opita ga starac: Ako bi ča videl? prema lat. Venit senex ad illum fratrem, et interrogavit illum, dicens: Aliquid vidisti?; A on' mu e odgovoril' prema lat. Ille autem respondens dixit $e i)^{36}$ nego se tijekom sažimanja teksta nerijetko izostavlja barem jedan glagol (niki fratar bi otil' v'zeti mô̂ h'cer za ženu prema lat. Ecce quidam monachus venit ad me, volens accipere filiam meam.). ${ }^{37}$

Skromne amplifikacije najčešće se pojavljuju u obliku kontaktnih sinonima, jednoga od najčešćih stilskih postupaka hrvatske srednjovjekovne proze: nesriĉ'nu trudnu, smradom' $i$ špotom, špotahu se i govorahu. Kao i u većini primjera iz drugih glagoljskih rukopisa jedan član sinonimnoga para nerijetko uključuje uporabu tuđice ili prilagođenice. Na nekoliko mjesta u Disipulima kao uvjetno rečeno kontaktni sinonimi spominju se oprost i pokora, uobičajeni pojmovi kasnoga srednjovjekovlja: da mu e b(og) pros'til i priel pokoru negovu (B, 3a) prema lat. Ecce suscepit Deus poenitentiam tuam. ${ }^{38}$

Osim kontaktnih sinonima u ovu skupinu ulazi i dodavanje posvojne zamjenice u postpozitivnom položaju na samome kraju egzempla: Od sada neĉu tebe os'taviti, ot'če, do semrti moe (B, 3a) prema lat. Ecce amodo tecum ero donec moriar. ${ }^{39}$ Da je riječ o stilskom obilježavanju, naznačuje i unošenje riječi semrt čije je pojavljivanje bilo najčešće uvjetovano književnom tradicijom (Damjanović 2014: 75).

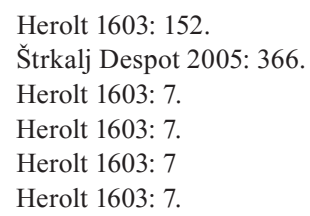


Nerijetko u dijalozima nailazimo na pojavu sitnih ekspanzija u pitanjima nakon kojih slijede kontrahirani odgovori. U Disipulima otac Makarije vragu ne upućuje neutralan pozdrav (salveris), nego pitanje Esi li ča tamo van'cal?, na koje očekuje pozitivan odgovor s obzirom na trud koji je đavao uložio s namjerom da smuti fratre darivanjem raznih primamljivih slatkosti: Greduci v kipi č(lovêč)skom v sviti platneni ka biše plna škulic i na vsakoi višă̌e niko okušenie (...) Grem smutiti fratre ki su v pustini i oĉu im dati ovih okušeni. Komu ne bude edno ugodno, ê mu drugo dam (D, 155r). Rijetka dodavanja teoloških tumačenja, tj. eksplanatornih elemenata, mogla bi biti pokazatelj određene načitanosti prevoditelja/pisara teksta. Tako se u svim prijepisima čin izlaska goluba iz monahovih usta simbolički tumači kao izlazak Duha Svetoga: $i$ učini mu se kako da bi golub' izletil' iz' ust' negovih n(a) n(e)bo, a to e bil d(u)h s(ve)ti (A, 3d) prema lat. Et statim vidit velut columbam exire de ore suo, et volare in coelum. ${ }^{40}$ Također, vražje iščezavanje nakon zavođenja monaha u egzemplu o vragu koji u obličju edne lipe žene $e^{41}$ posjećuje pustinjaka opisuje se kao čudo (Na to čudo špotahu se i govorahu.). Pojavljivanje upravo te riječi označava to da je pisar/prevoditelj bio upoznat s anegdotama već spomenutoga Ivana Egipatskoga (Narratio abbatis Joannis de eo qui lapsus est $),{ }^{42}$ monaškoga oca koji je bio poznat po promicanju poniznosti, ali i pripovijedanju raznih čudesa, a ponajviše onih usredotočenih na poučavanje o opasnostima pohote i čuvanju monaške čistoće. ${ }^{43}$

Autoritet određenih riječi u egzemplima ističe se jezično-stilskim postupcima: uporabom starijega prijevoda biblijskoga citata i ad verbum prijevodom. Takva jezična diferencijacija jasno odvaja iskaz pripovjedača (propovjednika) od iskaza svetoga oca, a donekle bi se mogla povezati s običajem hrvatskih glagoljaša koji su i u 16. st. u prijevode biblijskih citata katkad unosili hrvatskocrkveno-

\footnotetext{
40 Herolt 1603: 7.

${ }^{41}$ U svojim pohodima đavao se nerijetko prerušavao u razne zavodljive figure, a naročito privlačne žene (v' kipi edne lipe žene), a sve kako bi ih svojom lukavošću odmaknuo od Boga (Radošević 2016b, prema Le Goff 1998: 221). Najpoznatija anegdota s tim motivom u Vitae Patrum završava pustinjakovim paljenjem prstiju (Salisbury 2010: 54).

42 Herolt 1603: 7.

43 „Djevičanstvo se najprije smatralo jednim od najuzvišenijih oblika ćudoređa kojim je kršćanstvo ostavljalo izuzetno snažno svjedočanstvo u svijetu. Djevičanstvo je najbolji pokazatelj na koliku su askezu i odricanje bili spremni kršćani, jer ističu do koje mjere netko može živjeti čestito i uzdržljivo u svijetu (...) monaška duhovnost zamjenjuje duhovnost mučeništva." (Bodrožić 2015: 433, 436). Stoga ne iznenađuje što je „vražje omiljeno sredstvo odvraćanja redovnika od ispravnog života bio je poticanje na blud” (Tatarin 2003: 6).
} 
slavenska obilježja. ${ }^{44}$ Tako se uputa starijega oca, inače uobičajena crtica iz života monaških zajednica u kojima su se iskusni oci brinuli o duhovnom razvoj mladih monaha, ${ }^{45} \mathrm{u}$ svim prijepisima pojavljuje u vjernom ad verbum prijevodu: kada ti pride takovo smuĉenie i reci: ,E uzrok nisam tvoega huleniê v'rhu tebe budi, sotono, ere toga duša moê neĉe, a ki godi uzrok duša neĉe ta ne more d'lgo prebivati'(A, 42c) prema lat. quando haec cogitatio venit ad te dic: ,Ego causam non habeo, blasphemiae super te Sathana sit, hanc enim causam anima mea non vult. Quamcunque enim causam anima mea non voulerit, non diu permanebit. ${ }^{46}$ Pokazatelj je to da se u kontekstu propovjedne proze pustinjski oci ne pojavljuju isključivo kao protagonisti određene anegdote i egzempli pojedinih vrlina, nego kao autoriteti čije se riječi prenose s posebnom pozornošću.

Važnost opomene koju izgovara množastvo inih' dêv(a)l u Disipulu C istaknuta je i na jezično-stilskoj razini uporabom starijega oblika biblijskoga citata koji je tipičan za hrvatskoglagoljske liturgijske knjige (Uči se nebore ki se vznaša ta se s'mera $)^{47}$, tj. citata kojim je pripovjedač publiku podsjećao na tekst koji joj je vjerojatno bio poznat. Na paralelnom mjestu u Disipulu $B$ citat se pojavljuje u obliku: uči se nebore ki se vznaša ponizi se, 134c.

U našim je prijepisima zanimljivo pojavljivanje dviju naizgled sličnih sintagma: uide me va us'ta (B, 3ab) i mi uide va us'ta (A, 3d). Posljednji spomenuti izraz vjeran je prijevod latinskoga izraza (illa autem surgens intravit in os meum ${ }^{48}$ ) koji simbolički označuje povratak Duha Svetoga u dušu mladoga redovnika. Za drugi se prijepis može uvjereno reći kako je doslovno značenje (golubov ulazak u redovnikova usta) istisnulo ono simboličko jer opis golubova slijetanja na redovnikovu glavu završava uidanjem u usta, vjerojatno zbog suviše racionalnoga razmišljanja kako njegov realni ulazak nije moguć.

Zbog same strukture propovijedi i zakonitosti propovjednoga žanra u egzemplima najčešće izostaju pripovjedačeve interpretacije zbivanja. Motivacija unosa egzempla unaprijed se najavljuje s obzirom na to da se egzempl najčešće po-

\footnotetext{
$44 \quad$ Radošević 2017.

45 Uloga starih otaca u prvim stoljeća monaštva bila je „gotovo sakralna i nenadomjestiva” (Moro 2004:

51). Njihove savjete i naredbe mladi su monasi poslušno izvršavali (Harmelss 2004: 209).

46 Herolt 1603: 113-114.

47 U tom se obliku, navodi Lučić (2009: 198), navedena parafraza Lukina evanđelja $(18,14)$ nalazi u Reguli sv. Benedikta (ki se vznaša smêrit se a smêraei se vznosit se) i 4. vatikanskom misalu (vsak' vznosei se smêrit se a smêraei se vzneset se).

48 Herolt 1603: 7.
} 
javljuje na kraju obrazloženja određenoga stajališta utemeljenoga na tvrdnjama istaknutih autoriteta: Svetoga Pisma, crkvenih otaca i naučitelja, pa čak i srednjovjekovnih autora. Propovjednik je ujedno i pripovjedač koji promjenu diskursa najavljuje izrazom čte se uvodeći time svoju publiku u pripovijedanje. Uvod u egzempl o vragu koji u obličju lijepe žene posjećuje monaha, koji se pojavljuje kao krajnja opomena u zaključku 107. propovijedi, sastavljen je od tumačenja citata iz Komentara na Matejevo evanđelje Ivana Zlatoustoga: Na to Krzo(stom) vrh M(a)tê gov(o)ri: „O, nerazum'ni, ča tebi prudi ono hv(a)l(e)nie po sem'rti kim' sada hv(a)liši se." Zato imamo se čuvati da za dobra dela naša taĉe ne gov(o)rimo i tako e da mis'li naše ne v'zvisimo. Na to čte se takov eks(e)$m(p l)(\mathrm{A}, 94 \mathrm{r})$.

Promjena recepcijsko-pragmatičkoga konteksta ${ }^{49}$ između Vitae Patrum i latinskoga djela Sermones Discipuli, a zatim Heroltove zbirke propovijedi i Disipula, vidljiva je na više razina. Prvo je kontrahiranje onih dijelova teksta u kojima se opisuju motivi iz monaškoga života, postupak koji zatječemo već u latinskoj zbirci propovijedi i koji se nastavlja provoditi u Disipulima.$^{50} \mathrm{U}$ kratkom egzemplu o redovniku koji se sramio vražjega iskušenja izostavlja se ime pustinjskoga oca (Poemen) $)^{51}$ i opis njegove sposobnosti čitanja misli, što je zapravo glavni razlog redovnikova posjeta. Tematika ove propovijedi, u kojoj se raspravlja o negativnome utjecaju konstantne zabrinutosti ljudi zatrovanih raznim brigama i malodušnošću, a koja u konačnici onemogućuje duhovni razvoj, dobrim se dijelom podudara s monaškim tumačenjem pojma misao (cogitatio). Misao, odnosno razmišljanje, u prvim stoljećima kršćanstva imala je pretežito negativna značenja: borba s iskušenjima, preispitivanje, zabrinutost, opsesivnost (Harmless 2004: 229).

Ne samo što se monaški motivi pojavljuju u znatno manjem opsegu u odnosu na Vitae Patrum, nego se u Disipulima oni katkad zamjenjuju motivima kasnoga srednjovjekovlja. To se ponajviše očituje u zamjenjivanju i dodavanju riječi

\footnotetext{
$49 \quad$ Zlatar 2001: 79.

50 Primjerice, detalj iz Disipula A, u kojem se nalazi nešto kraća verzija egzempla, sadržava rečenicu koja opisuje važan podatak iz povijesti monaških zajednica, a odnosi se na odnos mlađega i starijega monaha. U pripovjedačevu iskazu $i$ k(a)ko mu e povidal lagle mu e bilo kriju se dva bitna detalja potrebna za shvaćanje monaštva općenito. Prva je iznošenje (ispovijedanje) svih misli starijemu monahu, a druga je motiv liječenja, tj. njegovo davanje savjeta i pomaganje u duhovnom životu.

${ }_{51}$ Tendencija da se publika ne opterećuje nepotrebnim podatcima općenito je prisutna u srednjovjekovnim egzemplima koji su nastali kraćenjem izvornih duljih narativnih tekstova.
} 
povezanih s ispovjedno-pokorničkom tematikom (grijeh, pokora, ispovijed) na mjestima na kojima se u latinskom predlošku pojavljuju pojmovi razmišljanja, budnosti i sl. Naime, u monaškom kontekstu stanje stalne pozornosti jedna je od stvari koja pustinjake čuva od iskušenja. ${ }^{52}$ Dok je u Disipulu A krajnja uputa gotovo podudarna s onom iz pustinjskoga vremena, pri čemu se naglasak stavlja na zamiranje, $\mathrm{tj}$. poticanje na stanje stalne budnosti i opreza u čuvanju od napasti i iskušenja (Naiprvo zamirai i budi skrban' i čuvai se prehineniê), u Disipulu $B$ zamiranje i čuvanje od prehinjenja prelazi u registar grijeha (budi skrban' $i$ dai hv(a)lu b(og)u i ne sagriši prema lat. de caetero attende temetipsum, et esto sollicitus). ${ }^{53}$

U pojedinim prijepisima mijenjaju se završetci, a time i krajnja poruka egzempla. U egzemplu o Makariju i vragu u Disipulu $C$ težište nije na prikazu Makarijeva nadmudrivanja, nego na isticanju Teopencijeva čina pokore i ispovijedi: I potom ni d'êval' smil tamo priti ciĉa is'pov(ê)di i pokore Teopen'cieve ku se e nemu protiv(i)l $(\mathrm{C}, 67 \mathrm{v})$. Takva promijenjena poruka u kojoj je nekoliko rečenica zamijenjeno dodanom sintagmom u skladu je s tonom propovjedne zbirke u kojoj se neprestano na razne načine potiče na kajanje, pokoru i ispovijed. Odraz je takva stava i zamjenjivanje sintagme is'povii s'voê zala miš'leniê izrazom is'povi v'se svoe grihe u Makarijevoj uputi Teopenciju. Naime, od 13. st. ispovijedanje označava ispovijedanje grijeha, dok se u monaškom kontekstu taj događaj odnosio na dijeljenje zlih misli (povida mu sve po redu).${ }^{54} \mathrm{U}$ egzemplu o vražjem posjetu pustinjaku nekoliko se puta upozorava na opasne misli, tj. na razne oblike razmišljanja koji u konačnici udaljuju od spasenja. Na samome početku egzempla monahova se oholost i hvalisavost iskazuju riječima kako $v$ svoei misli se e vzviševal ciĉa svoih dobrih del te upravo zbog takva stava na kraju biva važgan' zlim' miš'leniem. Za razliku od Vitae Patrum, u kojima ova anegdota završava tumačenjem kako se monah nije trebao predati malodušnosti, već je trebao potražiti pomoć starijega monaha, u latinskoj zbirci egzempl završava prikazom monahova srama i konačna izlaska iz reda.

Verzija egzempla $O$ čovjeku koji se sramio vražjeg iskušenja iz Disipula B bliža je izvorniku te bolje pogađa monašku duhovnost. Usuđujemo se reći kako je

Moro 2004: 52.

Herolt 1603: 7.

54 Harmless 2004: 229-232. 
čak sitna parafraza (zamjenjivanje riječi žalostan izrazom nesuĉi e s' sobu) još više nego u latinskoj propovijedi pogodila kontekst monaškoga razgovora. Takvim izborom riječi ovaj egzempl zahvaća širi spektar pojedinaca koji se bore s raznim mislima, tj. ne samo onih žalosnih i skrbnih, nego svih onih koji svoje misli odnose sa sobom ne uspijevajući ih podijeliti sa starim duhovnim ocem ( $t i$ vele krat prihodiš' k meni imeûci i mišleniê i opet greš t'ê nesuĉi e s'sobu (B, 19d) prema lat. Ecce frequenter venis ad me habens cogitationes et sic iterum remeas tristis). ${ }^{55} \mathrm{U}$ Disipulu $A$ na više se mjesta monahove misli opisuju u ipak nešto užem značenju: monah dolazi skrban, odlazi žalostan te se bori sa smuĉeniem (Nu, s(i)nu, ti vele krat' prihaês' k' meni skrban' i opet' odhaês' žalos'tan).

Usporedba je pokazala kako pojedini egzempli nemaju u svim prijepisima isti završetak: dio ih ostaje vjeran monaškom kontekstu, a dio ih poprima oštro srednjovjekovno stajalište prema svim vrstama grijeha. Primjer koji najbolje ilustrira takvu promjenu nalazimo u egzemplu o sinu poganskoga svećenika koji promatra prinošenje žrtve vražjih sluga, a koji se nalazi u dvjema latinskim propovijedima: u 40. propovijedi o iskušenju dobrih ljudi (De tentationibus bonorum hominum) te u 87. propovijedi o obraćenju grešnika (De conversione peccatoris) $\mathrm{s}$ kojom je dospio u glagoljske Disipule. Ta se anegdota nepoznatoga pustinjskog oca iz provincije Tebajde rado prepričavala u srednjovjekovnim tekstovima, pogotovo u onima koji su skretali pozornost na sveprisutnost vražjih iskušenja, postavljanja raznih zamki među kojima je svakako najomiljenija bila ona koja je monahe navodila na pohotno ponašanje (Van Doom-Harder 1995, Salisbury 2010: 51-52). Razmjeri veselja koje vragu donosi moralni pad samo jednoga redovnika više nego zorno prikazuje opis njegova nagrađivanja sluge koji je 40 godina uporno nagovarao redovnika na blud sve dok ga jednoga dana nije slomio. Upravo se iskušavanje pohotom smatralo jednim od najučinkovitijih načina izlaska redovnika iz reda: da oĉe van' iz reda poiti. U Vitae Patrum anegdota završava odlukom sina poganskoga svećenika da postane redovnikom, koju donosi nakon što čuje vražji izraz oduševljenja uslijed uspjeha posljednjega spomenutog sluge zbog kojega je redovnik prekinuo zavjet čistoće. Iako se u dobrom dijelu svoje zbirke Herolt snažno obrušava na razne oblike grijeha, s obzirom na to da je središnja tema ove propovijedi obraćenje grešnika, dominikanac u ovom slučaju ne intervenira znatno u tekst pustinjačke anegdote: promatranje vražjih

55 Herolt 1603: 113. 
sluga, koji se dolaze pokloniti svojemu gospodaru, a koje na kraju motivira sina poganskoga svećenika da se preobrati i postane redovnikom, prema načelu ad usum laicorum ohrabrivalo je sve okorjele grešnike da se obrate. Ta je monaška poruka u cijelosti prenesena jedino u Disipulu A, za razliku od Disipula B i D koji, završavajući slikom vražjega veselja, šalju znatno oštriju poruku.

Egzempli u Disipulima, kao i u Heroltovoj zbirci, ne prenose uvijek istu poruku kao u Vitae Patrum. Anegdota o Makariju pojavljuje se u funkciji ilustrativnoga narativnog argumenta središnje tvrdnje drugoga dijela propovijedi, a odnosi se na uvjeravanje u svakodnevnu izloženost čovjeka vražjim iskušenjima. Nastojeći istaknuti tematiku iskušenja, a ne prodiranja u svijest monaha, Herolt fokus stavlja na vražje iskušavanje redovnika. Za razliku od anegdote iz Verba seniorum, u kojoj pratimo Makarijevo postupno prodiranje u unutrašnji svijet monaha Teopencija (a što mu uspijeva tek nakon što s njime podijeli svoje unutarnje borbe), u latinskoj zbirci i u Disipulima središnja tema nije fornicatio, nego iskušenje. U središtu dominikanskoga egzempla stoji razgovor između Makarija i đavla, a dug razgovor između Makarija i Teopencija,${ }^{56}$ koji u Vitae Patrum čini njegov središnji dio i u kojem su prikazane pojedine crtice iz asketskoga života monaha, sveden je na svega jednu rečenicu: A opat' e šal' iskati cele Teopen'cieve i rekal mu e: „Sinu, ispovii v'sa tvoe zala miš'leniê!!” (A, 66b).

\section{Jezik egzempla Vitae Patrum}

Jezik glagoljskih Disipula Štefanić opisuje kao čakavski „s dosta konzervativnih elemenata u kojem se osjeća u pogledu leksika blizina njemačkog i kajkavskog narječja, više puta probija latinska konstrukcija, a u biblijskim citatima nastoji se dati tradicionalni slavenski tekst" (Štefanić 1969: 236). Hercigonja (1974: 198) zajedno ih s Homilijarom na Matejevo evanđelje i Žgombićevim zbornikom svrstava u zapadnu istarsku skupinu glagoljskih rukopisa u kojima je čakavska osnova prožeta kajkavskim crtama. ${ }^{57}$ Riječ je o čakavskome jeziku s ikavsko-ekavskim refleksom jata u kojem nalazimo neke značajke karakteristične za

\footnotetext{
56 Razgovor koji izostaje u Heroltovoj zbirci prikaz je uobičajena, ali vrlo važna odnosa monaha i njegova duhovnoga oca (opata), na kojem zapravo počiva monaška zajednica. Riječ je o razgovoru koji je najsličniji današnjemu pojmu ispovijedi, s tim da cilj nije bio otkriti grijehe, nego misli.

57 Vidi Radošević 2016a.
} 
sjevernu čakavštinu. Potvrđeni su primjeri starijih (hrvatskocrkvenoslavenskih) gramatičkih oblika, no najčešće nalazimo paralelnu uporabu novijih čakavskih oblika.

\subsection{Glasovne značajke}

U tekstu nalazimo više primjera jake vokalnosti koja je obilježje čakavskih govora: $\check{c} a(\mathrm{C}, 22 \mathrm{v} ; \mathrm{B}, 157 \mathrm{~b} ; \mathrm{A}, 66 \mathrm{~b}), z a c ̌(A, 66 \mathrm{~b} ; \mathrm{C}, 67 \mathrm{v} ; \mathrm{A}, 3 \mathrm{~d} ; \mathrm{B}, 3 \mathrm{a})$, kadi (A, 42d; B, 19d), zalalzali/zaloga (A, 66b; C, 67v; B, 19d; D, 19v). Iako kod pridjeva zao pretežu primjeri jake vokalnosti, nekoliko je potvrda u kojima ona izostaje: z'la (B, 157b), zlim' (B, 134d). Samo je jedna potvrda jake vokalnosti u I jd. lične zamjenice manu (B, 3a; D, 3r).

Prijedlog (prefiks) $v$ nekoliko je puta vokaliziran u va (va obrazi C, 22v; va se A, 94b; va us'ta, A, 3d; va nû B, 2d), no znatno se češće pojavljuje u nevokaliziranom obliku v (vednoi, A, 94b; v nega, C, 22v) i v' (v' kipi, B, 157a; v' sviti, A, 66b; v' koliki, A, 76a). Samo je jedan primjer vokalizacije u $u$ (u veliki, B, 76d; $\mathrm{D}, 68 \mathrm{v})$. Na početku glagola čuva se $v$ (v'splakal, A, 3d) i vz (v'zdišući, B, 3a; vzdvizaše, B, 134d; v'zdal, A, 3d; v'zbudil', A, 76a; v'zv'isil, C, 22v; v'zeti, A, 3c, B $2 \mathrm{~d} ;$ vznaša, C, 22v). Jedine potvrde vokalizacije u va nalazimo u primjerima važgal' (B, 134d) i vačnet (A, 75c).

Slogotvorno /1/ devokalizirano je u nekoliko primjera u mlađemu Disipulu D: ispuni, ispunivši $(\mathrm{D}, 3 \mathrm{r})$, puteno $(\mathrm{D}, 53 \mathrm{r})$. U ostalim prijepisima nije provedena devokalizacija: is'plni (B, 3a), is'plniv'ši (B, 3a), d'lgo (A, 42c). Svega je nekoliko primjera devokalizacije slogotvornoga/r/ (smerti, D, 3r; kervi, D, 53r; skerban, D, 3r; sverši, D, 2v), ali većina se njih nalazi u najmlađemu Disipulu D. Nekoliko je primjera pronađeno i u ranijim prijepisima, kao što je vokalizirani oblik tere (A, 3d), koji se u drugome rukopisu na paralelnome mjestu pojavljuje kao $t r^{\prime}$ (B, 3a). Nema potvrda za čakavski refleks prednjojezičnoga nazala /ę/ u /a/ iza palatala /j/, /č/, ali ima jedna potvrda refleksa iza palatala /ž/ (množastvo, $\mathrm{B}, 134 \mathrm{~d})$. Suglasničke skupine $j t-/-j d$ - ostaju nepremetnute u prezentu i infinitivu prefigiranoga glagola: poiti (A, 3c), poide (B, 2d). Refleks praslavenskoga */d'/ čakavski je /j/ koji se piše samoglasnicima, ali se bilježi i apostrofom. Skupina žd reflektirala se u glas /j/: prihaêš (A, 42b), odhaêš (A, 42b), mêu (D, 53r). 
Rotacizam je dosljedno proveden: more, ere, nebore. Suglasnički skup /čt/ samo je u jednom primjeru u najmlađemu Disipulu D prešao u /št/ (šte se, D, 53r).$^{58}$ Također nema metateze u suglasničkoj skupini /vs-/: vs(a)ki, vsi, vsa, vse.

Zabilježeni su primjeri u kojima izostaje sekundarna jotacija: tretih (A, 3c), treti (B, 58b; D, 53r), dêv(a)l (B, 76d; A, 66b; C), d'êv'la (B, 49b; C, 67v), t'ê (B, 19d, 157a; A, 66b), t'iê (D, 19v). Ima i dvojnih oblika, kao što pokazuje imenica čistoĉa, kod koje u D jd. izostaje jotacija (nečistoti, B, 134d), dok se u L jd. pojavljuje (v čistoĉi, A, 94b). U Disipulu A, u kojemu nalazimo oblik s jotacijom, zabilježen je N jd. čis'tota (A, 76b).

Nekoliko je primjera gubljenja početnoga /i/ u prefiksu iz-: zmislil' (B, 134c), zmišlivati (C, 22v), što je poznata čakavska crta (Malić 2002: 177). Svega je nekoliko primjera redukcije $l<v l, t r<t v r: \check{c}(e) t r t i<\check{c} e t v r t i$ (B, 58c; D 53r), obladal' < obvladal (B, 58c; D 53r).

U najmlađemu Disipulu D pronađen je primjer gubljenja završnoga /j/ u imperativu: znamenu (D, 19v). (Malić 1997: 505). Postoje primjeri disimilacije inicijalnoga $m n>v n$ : vnoga, v’noga $(\mathrm{B}, 49 \mathrm{~b})$. Bilježimo i primjere promjene $k>h$ : h'cere (A, 3d), h'cer (B, 2d).

Glagol hotiti potvrđen je samo u obliku bez početnoga /h/: otil, C, 67v; otil', A 3c; otel', B, 157b; oĉ, B, 157b; oce, A, 3c. Na kraju participa preterita aktivnoga drugog redovito nalazimo /1/ kao završni fonem: prišal' (B, 134c, C, 22v), rekal' (A, 3c), zamiral (B, 157b), namural (A, 3c), izletil' (A, 3c), potopil (B, 58b), činil (B, 58c), sramoval' (A, 42b).

Slovo đerv pojavljuje se svega nekoliko puta, i to najčešće u 3. 1. jd. glagola biti (je), u superlativu (naioštrîjie) te u jednome primjeru 3. 1. mn. prezenta glagola iziti (iz’’jidu). Iako je ovo očita potvrda prejotacije kao karakteristične pojave za mnoge čakavske govore, i primjer $i z$ ' $i$ također može ozačavati prejotaciju jer u Disipulima ima potvrda da se jotacija bilježi i apostrofom. ${ }^{59}$

Udvajanje suglasnika nalazimo samo u jednome primjeru: pus'tinnika (B, 134c), pustin'nika $(\mathrm{C}, 22 \mathrm{v})$. Zanimljivo je da se apostrofi nalaze na istim mjestima kao

\footnotetext{
58 Oblik šte znatno se češće u odnosu na čte pojavljuje u Fatevićevu zborniku (Galić 2018: 157), koji je nastao svega 17 godine poslije najmlađega Disipula D.

59 Sličnu situaciju Malić (2002: 178) nalazi u glagoljičnim spomenicima 16. i 17. st. koji potječu sa šibenskoga otočja.
} 
u Berčićevu zborniku br. 5, gdje stoji pus'tin'nolûb'na (24r).$^{60}$

U Disipulima je refleks jata ikavsko-ekavski, uz znatno više ikavskih pojavnica: zvir (B, 134c; C, 22v), višaše (A, 66b; B 157a), vim (A, 3d), vrimeni (A, 76a), zamiral (B, 157b), sagriši (B, 3b). Manje je pojavnica koje se isključivo javljaju s ekavskim refleskom (bežal, B, 134d; ses'ti, B, 58c; delih, A, 94b). U Disipulima se uglavnom potvrđuje pravilo Meyera i Jakubinskoga (divoiku, A, 3c; grihu, B, 134d; lipe, B, 134c; niki, B, 157a; višaše, A, 66b; dela, B, 76d; ses'ti). Ima i mješovitoga refleksa jata: u korijenskim (sin, C, 22v; sen, B, 134d), prefiksalnim (pristolu, pres'toli) i sufiksalnim morfemima (vidil, videl; otil, otel).

U gramatičkim morfemima preteže ikavski refleks, u prefiksu nê- ikavski (nikoga, B, 58c; niko, A, 66b), dok se u prefiksu prê- podjednako pojavljuju primjeri s ikavskim (priletil', A, 3d; priletel, D; pristolu, B, 58b) i ekavskim (prebival, A, 66b, C, 67v; pres'toli, A 76a) refleksom.

Na kraju riječi jat je redovito ikavski: naiposlii (B, 19d), kadi (A, 42b; B, 58b), dokli (B, 2d; A, 66b), on'di (B, 134d). U participima se pojavljuje ikavski (zabludil, B, 134c; vidil, C, 67v; otil, C, 67v; smil, C, 67v; zatail, A, 3d; izletil, A, 3c; sidil', A, 76b) i ekavski refleks jata (živel, B, 76d; videl, A, 66b; otel', B, 157b; imel' A, 66c). Particip je glagola vidêti u Disipulu C ikavski, u Disipulu B redovito ekavski, a u Disipulu A izmjenjuju se ikavski i ekavski (vidil, vidil', videl, videl'). Nekoliko je primjera istodobnoga postojanja dvojnoga refleksa: npr. vidil (C, A) uz ipak češći videl; otil (C, A) i otel (B); povidal (A, B) i povedal (B). Jedini glagol koji u više oblika ima samo ekavski refleks glagol je imêti: imel (A, B), imeûci $i(\mathrm{~B}, 19 \mathrm{~d})$. S druge strane, kod glagola živêti refleks jata nije isti u svim oblicima: u participu u svim Disipulima imamo ekavski refleks (živel, B), a u imperfektu u Disipulu B ikavski (živihu, 157a). Također nalazimo primjer izmjenjivanja participa s ikavskim refleksom s onim u kojemu se još uvijek čuva jat: zataêl (B, 3a), zatail (A, 3d).

Nekadašnji poluglas povremeno se obilježava apostrofom. Nalazimo ga na krajevima riječi (prebival', A, 66b; rekal', B, 2d), u sredini riječi između dvaju suglasnika uključujući i posuđenice (tem’pli, B, 58b; dešperal', B, 134d), na granici sufiksa/prefiksa i korijena (rek'ši, B 157a; od'vratil', B, 157b). Kratki prijedlozi podjednako se pojavljuju s apostrofom i bez njega $\left(v, v^{\prime}, k, k, s^{\prime}, s\right)$.

60 Galić 2018: 112 . 
Samo se katkad apostrofom označava i jotacija: ž(i)vl(e)n’i (A, 42b), okušen'i (A, 66b). Više je primjera stavljanja apostrofa iza prvoga slova ako je to prvo slovo suglasnik (š́potom', B, 134d; k'ričati, C, 22v; c'vatuci i, A, 94b; s'voê, A, 94b). Neki primjeri učestale uporabe štapića mogli bi biti pokazatelj ostatka pisarske tradicije: ${ }^{61}$ s'rama (B, 134d), s'tarče (C, 22v), s'lat'ko (A, 66b), s'luge (A, 66b).

\subsection{Morfološke značajke}

U L jd. m. r. i s. r. češće se pojavljuje stariji nastavak -i (v kipi, B, 157a; v’životi, A, 3c; v' mori, A, 76a; v vrimeni, A, 76a; na pres'toli, A, 76a), a svega nekoliko puta noviji nastavak - $u$ (v kutu, B, 134c; na pristolu, B, 58b). ${ }^{62} \mathrm{U}$ I jd. m. r. i s. r. nalazimo nastavak -om, -em (špotom, B, 134d; smradom, C, 22v), osim kod riječi lûdi, u kojoj nalazimo nastavak -i (mê̂u ludi, B, 58b; D, 53r). U A mn. m. r. zabilježen je nastavak - $i$ u riječi lûdi (A, 42a). U V jd. m. r. pojavljuje se nastavak -e (d'êvle, C, 67v; otče, A, 3d; s'tarče, C, 22v), osim u riječi sin, gdje nalazimo $-u\left(\operatorname{sinu},{ }^{63} \mathrm{~A}, 42 \mathrm{c} ; s(i) n u, \mathrm{~B}, 19 \mathrm{~d}\right)$.

U A jd. ž. r. potvrđen je nastavak -u $(g l(a) v u, A, 3 d)$. U V jd. ž. r. nastavak -o (sotono, B, 19d; D, 19v; A, 42v). U I jd. ž. r. nalazimo nastavak - $u^{64}$, koji je tipičan za sjevernočakavsko područje (s' niku ženu, A, 76c). U L mn. ž. r. nastavak je -ah (v rukah', C, 22v; v dobrotah, B, 76d; D, 68v; v kn(i)g(a)h, A, 3c). U I mn. ž. r. nastavak je -ami (dobrotami, B, 134c). U G mn. svih triju rodova najčešći je nulti nastavak (del, D, 68v; l(ê)t, B, 76d; škulic', C, 67v; flaščcic, C, 67v; žen', $\mathrm{B}, 2 \mathrm{~d}$ ), a nastavak -ov nalazimo samo u primjeru fratrov' (A, 66b; C, 67v) kao utjecaj u-promjene. ${ }^{65}$

U deklinaciji ličnih zamjenica jedan je primjer jake vokalnosti: I jd. (manu). Većinom se javljaju u oblicima: mene/me, nemu/mu, meni/mi, nega/ga, nim/'im. Nalazimo stare oblike pokaznih zamjenica $\mathrm{N}$ jd. m. r.: ta (A, 66c - na paralelnom mjestu u B stoji on') is' (ovaj, ova). Zamjenice i pridjevi u G jd. m. i sr. r. te

\footnotetext{
61 Galić 2018: 108.

${ }^{62}$ Miješanje starijih i novijih nastavaka u L mn. Malić (2002: 338) nalazi u najstarijim hrvatskim spomenicima.

${ }_{63} \mathrm{Na}$ čuvanje gramatičkih morfema u-deklinacije upravo u riječi sin upozorio je još J. Vrana u studiji o Blagdanaru popa Andrije iz 1506. godine (prema Damjanović 2014: 79-80).

64 Štrkalj Despot 2010: 49.

65 Vince 2014: 116.
} 
u A jd. m. r. za živo redovito imaju dočetno - a (nikoga, A, 76a; niednoga, C, 67v; moga, B, 2d; pogan'skoga, A, 3c), a u D jd. m. i sr. r. dočetno -u (tomu, B, 58b; nikomu, A, 3d). L jd. m. i sr. r. ima redovno stari nastavak -m (nikom, B, 134c; $\check{c}($ lovế $)$ skom, B, 157a; A, 66b). Zamjenice su uglavnom pisane u kontrahiranom obliku: $k i, k u$. U L jd. ž. r. nalazimo primjere s gramatičkim morfemima -oi (nikoi, drugoi), sa starijim morfemom -ei (svoei, B, 76d; moei, B, 3a; gorinei, C, $67 \mathrm{v})$ i morfemom nominalne pridjevske deklinacije $-i$ (veli, veliki). ${ }^{66}$ Zanimljivo je da su sva tri oblika u jednom egzemplu upotrijebljena u svega nekoliko redaka, što svakako pridonosi njegovoj stilogenosti: v ednoi škuli u veliki pokori (...) v svoei misli $(\mathrm{B}, 134 \mathrm{c})$.

U prvome licu prezenta noviji je nastavak - $m$. Jedini primjer starijega oblika pre-

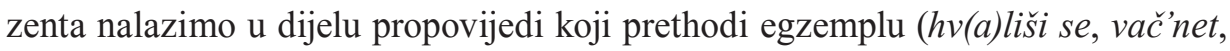
A, 75c). Futur se tvori isključivo naglašenim oblikom glagola htiti, u kojemu redovito otpada dočetno /h/. U najavi egzempla u Disipulu A (75c) na istoj stranici pojavljuje se dvojni oblik pomoćnoga glagola htiti u tvorbi futura prvoga: neĉe vratiti i nete vratiti, koji je tipičan za sjeverozapadnu čakavštinu. ${ }^{67}$ Buduća se radnja katkad izražava i prezentom: Od sada tebe ne ostavim otče do s'mrti (A, 3d).

U participu prezenta aktivnoga potvrđeno je $-\hat{c} /-\hat{c} i$ : govoreĉ $(\mathrm{C}, 22 \mathrm{v})$, čineĉi $(\mathrm{B}$, 134c), cvatucii (B, 76d; D, 68v), ufaûci (A, 94b). Postoji i primjer participa preterita aktivnoga prvog: iznam'ši (A, 76b), rek'ši (B, 157b; A, 66b), is'plniv'ši (B, 3a), prišad'ši (C, 67v).

U egzemplima je zabilježena jedna potvrda sjevernočakavskoga oblika s nastavkom $-h i^{68}$ za 1. lice jednine imperfekta: otihi (A, 3d; B, 3a).

U većini egzempla dominira pripovijedanje u perfektu. Participske konstrukcije ostaju ako se želi naglasiti dugotrajnost (živuci i) i ponovljivost radnje (greduĉi v, greduci od). Participi se najčešće zamjenjuju perfektom, a katkad se izbacuju.

Jedini primjer dvojine pojavljuje se kao dio stilskoga obilježavanja početka fizičkoga odnosa između monaha i lipe divoike: počela s'ta se smiêti i šaliti (B, 134c).

\footnotetext{
Hercigonja 2004: 396-397.

Štrkalj Despot 2010: 49.

68 Upravo ovim imperfektnim oblikom obiluje Pseudo-Anselmov Dijalog iz Žgombićeva zbornika, koji je jednim dijelom pisan sjevernočakavskim dijalektom.
} 


\subsection{Sintaktičke značajke}

Posvojnost se izriče genitivom ličnih zamjenica (nega misal, B, 134c; nega rukami, B, 134d; nega rukah', C, 22v; ocu ne, A, 3c), ali i posvojnim zamjenicama (ust' negovih, A, 3c; b(og) negov', A, 3d; pokoru negovu, B, 3b; knezov' negovih', B, 58c, D, 53r). Posvojne zamjenice češće se nalaze iza (b(og)a moga, A, 3c; ust' negovih, A, 3c; gl(a)vi moei, B, 3a; us'ta moê A, 3d), ali katkad i ispred imenice (moi b(og), A, 3d; t'vô̂ h'ĉer, B, 2d).

Adnominalni pridjev nalazi se ispred i iza imenice, najčešće ovisno o njegovu položaju u latinskome predlošku: v' kipi č(lovêč)skom (B, 157b; A, 66b) prema lat. in figura hominis; cele Teopen'cieve (B, 157b) prema lat. cellam Theopansii; h'cer ednoga popa pogan'skoga (A, 3c) prema lat. filiam sacerdotis paganorum. Ako je riječ o odmaku od doslovnoga prevođenja (primjerice proširivanja teksta), pridjev nalazimo ispred: niki star opat' (A 42b) prema lat. senex, ali i iza imenice: redovnik dobar (A, 76b) prema lat. monachus.

Nalazimo i nekoliko primjera romanskih konstrukcija sastavljenih od glagola činiti i infinitiva, ${ }^{69}$ a koje nisu rezultat doslovnoga prijevoda: činil' ga e biti (A, 76a); činil' ga e ses'ti (B, 58c); činil ga e sagrišiti (B, 76d), te onih sastavljenih od prijedložnog izraza od i imenica: ${ }^{70} e k s(e) m p l$ od' Makariê (A, 66b).

Zanimljiva je uporaba dvaju stilski obilježenih genitiva na mjestu akuzativa u latinskome jeziku: genitiva negacije (ne dai mu tvoe h'ĉere, A, 3d; ne dai mu e, B, 3a) i kvantitativnoga genitiva (toliko flaščic, C, 67v), koji su primjerice već u mlađim misalima uvelike uzmicali pred akuzativom. ${ }^{71}$

Zanimljiv je primjer prevođenja upravnoga govora ${ }^{72}$ kao kombinacije neupravnoga i upravnoga govora: I reče mu s'tarac da posti v(=3) n(e)d(ê)le po red', ,a ê oĉ b(og) a moliti za te.”(A, 3d) prema lat. Et respondens senex, dixit ei: , Sede mecum in spelunca, et ieiuna tres hebdomadas continuas, et ego deprecabor Deum pro te."

Sintaktički paralelizmi pojavljuju se kao rezultat sažimanja teksta, a uz njih se nerijetko javljaju kondicionalni oblici kao pokazatelji iterativnosti radnje: I kada

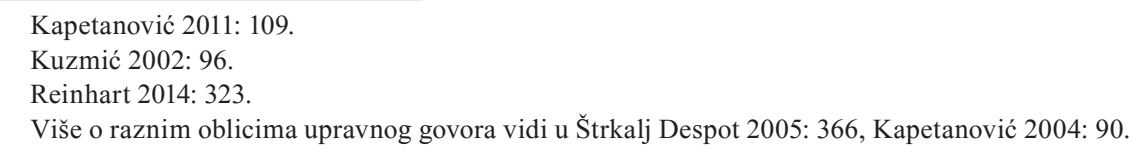


s'vrši prvu n(e)d(e)lû opita ga s'tarac: „Ako bi ča videl?” (...) I kada is'plni drugu n(e)d(e)lû, pital' e starac: „Ako bi ča videl?”(...) I is'plniv'ši v(=3) n(e)d(e)lû pital' je starac': „Ako bi oĉe videl'?”(B, 3a).

\subsection{Leksičke značajke}

U Disipulima ima nekoliko leksičkih crkvenoslavenizama: hrabarstvo u značenju 'vojska' (lat. militia) te otai u značenju 'tajno' (lat. occulte). Od tuđica izdvajamo germanizme (kušnul, špot, flaščica), talijanizme (vancat, namural, divicion, tenta) i latinizme (cela, tempal, dešperal). Latinizam cela potvrđen je još u Žićima svetih otaca iz 14. st. Riječ škula pojavljuje se u značenju 'špilja', a deminutiv te riječi (škulica) u značenju 'rupa na tkanini'. Riječ vancati (prema tal. avanzare) u značenju 'napredovati' u svim se rukopisima pojavljuje bez početnoga $a$-. U takvu je obliku ona zabilježena u mletačkome (vanzare) i tršćansko-furlanskome govoru (vanza), a u istom značenju pojavljuje se u Mošćeničkome statutu, ${ }^{73}$ tj. u tekstu nastalu na sjevernočakavskome području. U Disipulu $B$ nalazimo ranu

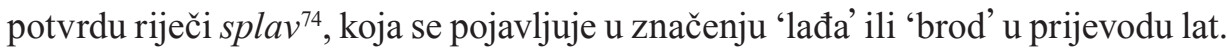
et submersi naves cum hominibus (potopil sam s'plavu). U Disipulu C nalazimo riječ flaščica u značenju 'staklena posuda', deminutiv riječi flaša koja je prema ARj (III: 60) zabilježena samo u Belostenčevu rječniku Gazophylacium i Voltićevu Ričoslovniku iliričkoga, italijanskoga i nimačkoga jezika. S obzirom na to da se ovdje ta riječ pojavljuje u deminutivnome obliku, može se pretpostaviti kako se upotrebljavala najkasnije već početkom 16. st. Na kraju istaknimo kako se lat. fornicatio prevodi na čak četiri načina, pri čemu se kombiniraju riječi blud, grijeh, sablazan, napast, žena i put: sagrišiti bludom's niku ženu (A, 76ab) i sagrišiti s'ženu plteno (B, 58c) prema lat.feci eum fornicari te kao sab'lazan od žen' (B, 2d) i napast od pl'ti svoe (A, 3c) prema lat. impugnabatur a fornicatione.

\section{Transliteracija egzempla}

Tekst je pripremljen prema fotokopijama izvornika koje se čuvaju u knjižnici Staroslavenskoga instituta. Za slovo đerv uzeto je $\hat{\jmath}$, za jus û, za šta ĉ, za jat ê, za apostrof '. Kraćene riječi razriješene su u okruglim zagradama. Interpunkcijski

Skok II: 579.

74 O leksemu splav vidi Budja 2018. 
znakovi i velika slova uneseni su prema latinskome tekstu objavljenu u PL 73. Početak folija naveden je unutar teksta. U sklopu ove studije utvrdila sam Heroltove predloške četiriju egzempla (1., 3., 4. i 5.) iz njegovih sermones de tempore i sermones de sanctis, dok sam podatak o predlošku 2. egzempla, unesena iz Heroltova Egzemplara, preuzela iz Hermandove studije iz 1995. Za svaki se egzempl nabrajaju paralelni tekstovi potvrđeni u raznim knjigama objavljenim u PL 73 i PL 21, pri čemu se navode njihove kratice (Pel., Pasch., Ruf., HL, HM) te redni brojevi stupaca (col.). Također se navode paralelni tekstovi iz Žića svetih otaca. Svaki egzempl donosi se u nekoliko prijepisa (ne u svima), pri čemu su obuhvaćena sva četiri rukopisa Disipula.

\section{Vrag zavodi pustinjaka u kipu lijepe žene}

U latinskoj zbirci egzempl se pojavljuje u 107. propovijedi De iactantia (Herolt 1603: 407-408). Utvrđeno je da je riječ o anegdoti koja se nalazi u HM 1 (PL 21, col. 399) i HL 44 (PL 73, col. 1147-1148 ). U Disipulima A (94b), $B$ (76d) i $D(68 v)$ zapisana je kraća, a u Disipulima $B\left(134 \mathrm{c}^{75}\right)$ i $C(22 \mathrm{v}-23 \mathrm{r})$ dulja verzija toga egzempla. Anegdota s djelomično sličnim uvodnim motivom, ali znatno drukčijim završetkom, nalazi se u Pel. V 37 (PL 73, col. 883-884.). Prema toj su anegdoti nastala dva teksta unutar Žića svetih otaca, i to pod nazivom Ot čistoće kao 37., odnosno 150. tekst (Malić 1997: 63; 161-162). ${ }^{76}$

\section{Disipul C}

Ča se s'kazue od nikoga pustin'nika ki se ukrašivaše m'nogimi dobrotami. I potom se e v'zv'isil misleĉi i ufaûci se na svoe dobrote. To videĉi nepriêtel d'êv(a)l prišal'e k nemu va obrazi lipe divoike čineĉi se da e zabludil gov(o)reĉ: ,S'tarče, mene nesriĉ'nu i trudnu /23r/ našla e noĉ v'pus'tini. Prosim te, pus'ti me totu pri sebi v nikom kutu prebivati da me zviri ne iz’jidu." A d'êv(a)l počel e zmišlivati slatke besede i nega e k sebi obratil i mế im smiêla sta se $i$ šalila. Potom e postavil ruku na gl(a)vu i na bradu i na vrat i važgal'se e tudie zlim' mišleniem $i$ počel'e nega ob'emati. I tada e d'êv(a)l v nega rukah'počel'strašno k'ričati is

\footnotetext{
75 Transliteracija egzempla koji se nalazi na f. 134c u Disipulu B objavljena je u Radošević 2016b: 213214.

76 U Žićima svetih otaca postoje dvije inačice sličnoga egzempla u kojem je pustinjak svoju strast prema ženi koja mu dolazi iznenada u posjet i koja ga tjelesno iskušava zatomio tako što je zapalio svoje prste.
} 
velikim smradom'i špotom z'gibal e k(a)ko sin'. I ostali d'êvli ki su bili prišli na to čudo špotahu se i gov(o)rahu: „O nesrichni, ki si se do neba v’zvisil k(a)ko si nisko v'pakli utonul. Uči se, nebore, ki se vznaša ta se s'mera." A on kako pres pameti i straha i prehineniê dě̌peral se e da se e dal nečistoti i grihu. I bižal'e od gledaniê s(ve)tih lûdi.

\section{Disipul B}

Bil'e niki fratar ki e živel v' ednoi špili u veli u veliki pokori. I veliko l(ê)t cvatuĉi $v$ dobrotah', ki v svoê dobra dela ufaûci a ne v B(og)a, nego va se i v'svoei misli se e vzviševal ciĉa svoih dobrih d(ê)l ka e bil' učinil. Tu misal videĉi dêv(a)l $i$ poznavši činil' ga e sagrišiti bludom' niki večer i bil ĵe osuen.

\section{Razgovor Makarija i đavla}

U propovijed Na Križevicu (lat. De exaltatione sancte crucis), koja pripada ciklusu sermones de sanctis, egzempl je unesen iz poglavlja o iskušenju (lat. Temptatio) Heroltova Egzemplara (Herolt 1603: 181-182). ${ }^{77}$ Tekst se unutar Verba seniorum, kako navodi Hermand, ${ }^{78}$ pojavljuje na čak tri mjesta: Ruf. 61 (PL 73, col. 769-770), Pel. XVIII 9 (PL 73, col. 981-982) i Pasch. I (PL 73, col. 10271028). Nalazi se u svim četirima Disipulima: $B\left(49 \mathrm{bc}, 157 \mathrm{ab}^{79}\right), A(66 \mathrm{bc}), C(67 \mathrm{v})$ i $D(154 \mathrm{v}-155 \mathrm{r})$.

\section{Disipul A}

Imamo eks(e)mpl od' Makariê ki e prebival' sam' v' gorinoi pus'tini, a dolina pus'tina bila e plna fratrov'. Edan'večer videl' e dêvla v' kipi č(lovêč)skom'v' sviti plat'neni ka e bila p’lna š'kulic' i na v'sakoi višaše niko s'lat'ko okušenie. I rekal' mu e starac': „Kamo greš, dêv'le?” Odgovoril' e: „Grem' s'mutiti fratre ki su v'dolinoi pus'tini.” I rekal'e s'tarac', „Zač nosiš' toliko okušen'i?”, ,Nosim' slatkos'ti fratrom', i ako im' edno ne bude ugodno ocu im' drugo podati." I to rek'ši šal'e t'ê. I tada e starac'zamiral dokli se vrati. I opital' ga e: „Esi li ča

\footnotetext{
${ }_{77}$ Zbirke propovijedi, Marijinih mirakula i egzempla u ovom izdanju imaju odvojenu paginaciju te se navedene stranice odnose na 3. dio (zbirku) latinskoga djela pod nazivom Promtuarium Exemplorum.

78 Prema Hermand 1995: 47.

79 Transliteracija egzempla koja se u Disipulu B pojavljuje na f. 157ab objavljena je u Radošević 2016b: 212-213.
} 
van'cal?”Od'govoril'e: „,V'si su mi se suprotivili.” A starac'e rekal', „Tada nimaš" tamo nied'noga s'luge!?” Od'govoril' e dêv(a)l: „Samo ednoga priêtela imam' ki me e poslušal.” I opital' ga e: „Kako mu e ime?” Rekal'e d'êv(a)l: „Teopen'cii.” A opat'e šal' is'kati cele Teopen'cieve, i rekal mu e: „Sinu, ispovii v'sa tvoê zala miš'leniê!" I t(a)ko e šal v svoû pustinû. I drugoč e videl d'êvla greduĉi od fratrov'. I pital' e: „Ča bi fratri činili?” A on reče: „Zlo, v'si su zdiv'êli i /66c/ samo ednoga sam'imel' ki me e pos'lušal'. I ta me se e odvr'gal'i neĉu tamo do m'nogo vrimena." I to rek'ši iceze.

\section{Disipul B}

Na to čt(e) se eks(e)m(pl) od b(la)ž(e)noga Makariê kada e prebival v pustini. Niki večer videl' e d'êvla va obrazi č(lovê)ka v sviti plat'neni ki nošaše vnoga okušeniê. I rekal mu e starac: „Kamo greš, hudobo?” Odgovoril' e: „Grem, s'mutiti fratre ki su v pustini." I rek(a)l e starac: „Ča nosišs' s' sobu?” Odgov(o)r(i)l e: „Nosim v'noga okušeniê, komu bude ed'no malo ê mu drugo podam.” I šal' e t'ê. I kada se e vratil pital ga e starac: „Esi li ča van'cal?” Odgov(o)r(i)l e: „,V'si su mi se protivili, nego samo ed(a)n me e poslušal.” Pital /49c/ e: „,Kako mu e ime?” Odgov(o)r(i)l e d'êv(a)l: „,Teopen'cii." I šal'e t'ê. A opat'e šal is'kati cele Teopen'cieve i rekal mu e da is'povi v'se svoe grihe i šal'e v'svoû pustinû. I opet'e videl'd'êvla od nih' greduci i pital'e: „Ča fratri čine?” A on r(e)če: „Zlo ere sam samo ednoga imel meû nimi ki me e poslušal, i onoga e niki od mene od'vratil'i oštriie od vs(i)h. I prisegal' sam'da neĉu tamo do velika vrimena." I šal'e t'ê s'voim putem.

\section{Disipul C}

Na to čte se eks(e)m(pl) od'Makarie. Bil e otac Makariê prebival sam'v gorinei pus'tini, a dolina pustina bila e plna fratrov. I ed(a)n večer vidil'e d'êvla prišad'ši va obrazi č(lovêč)skom v sviti plat’neni ka e bila p'lna škulic i na vs(a)-koi s’kulici višaše edna flaščica. I rekal e s'tarac: „Kamo greš, d'êv'le?” Odgovoril' e: „,Grem smutiti fratre v'dolinei pustini.” I rek(a)l e s'tarac: ,Zač toliko flaščcic nosišs?" Odgovoril'e: „Nosim'okušeniê fratrom, i ako im edna ne bude ugod'na ê im drugu podam ili tretu." I kada se e opet vratil pital' e starac: „Esi li ča van'cal?” Od'gov(o)ril e: „Ni nied(a)n otil pos'lušati moga s(vê)ta.” Rek(a)l e st(a)rac', „Tada nimaš niednoga prêt(e)la.” Odgov(o)r(i)l e: , Samo ednoga imam.” I 
pital e: „K(a)ko mu e ime?” Odgov(o)r(i)l e: „Teopen'cii.” I opat'e šal' iskati cele Teopen'cieve i rekal' mu e da ispovi s'voê zala mišleniê. I potom ni d'êval'smil tamo priti ciça ispov(ê) di i pokore Teopen'cieve ku se e nemu protiv(i)l.

III. O redovniku koji se htio oženiti kćerju poganskoga popa

Pojavljuje se kao završni egzempl druge propovijedi na Prvu nedjelju došašća (lat. Dominica I. Adventus) (Herolt 1603: 7). Utvrđeno je da se podudara s tekstom iz Pel. $\mathrm{V}_{38}$ (PL 73, col. 873). Ta je Pelagijeva anegdota zapisana i u Žićima svetih otaca pod nazivom Od ljub(v)e i molitve kao 38./151. tekst (Malić 1997: 64-67; 162-64). Egzempl se pojavljuje u Disipulima $A$ (3cd), $B(2 \mathrm{~d}-3 \mathrm{~b})$ i $D(2 \mathrm{v}-3 \mathrm{r})$.

\section{Disipul A}

Na to se čte v'Životi S(ve)tih otac'v tretih kn(i)gah eks(e)m(pl).

Bil'e niki fratar ki e imel'veliku napast od pl'ti s'voe i vidil'e niku divoiku, h'cer ed'noga popa pogan'skoga, i namural se e va nû. I rekal'e ocu ne: „, Dai mi t'vô̂ h'cer za ženu!” A on' mu e odgovoril': „Dati e neĉu dati dokli ne pitam b(og)a moga." I šal'e k' dêv'lu i rekal' e: „Niki fratar' bi otil'v'zeti mô̂ h'ĉer za ženu, oĉu li mu û dati?" Od'govori nemu dêval': „Ako zatai b(og)a s'voga i h(rstên)e $i$ da oce van' iz reda poiti, dai mu $\hat{u}$." I to e pop' povidal fratru, i tudie e fratar pris'tal'k tomu i učini mu se kako da bi golub' izletil' iz' ust' negovih n(a) n(e)bo, a to e bil d(u)h s(ve)ti. I povidal e pop' d'êvlu kako e videl' $i$ da oce fratar v'se te .v.(=3) /3d/ stvari učiniti. I odgovoril'e d'êval: „Ne dai mu tvoe h'cere zač" b(og) negov'ni od'šal od'nega, oce mu pomaga." I kada to s'liša fratar vele se e v'splakal i sam'k'sebi e rekal: „,Kada e meni moi b(og) toliko milos'tiv'buduci î nesriĉn'ni nega zatail', i h(rstêne) i red'tere mi oĉe pomaga, zač od'nega grem.", I brzo ide v' pustinû k' nikomu starcu i povida mu to vse po redu. I reče mu s'tarac da posti .v.(=3) n(e)d(ê)le po red', ,a ê oĉu b(og)a moliti za te.” I kada fratar pos'ti rečene .v. (=3) n(e)d(ê)le s velikim' divicionom' reče mu s'tarac': „Esi li ča vidil'?” On' e odgovoril': „Vidil' sam goluba da e priletil' nad gl(a)vu môे. I kada ga otihi eti učini mi se da mi uide va us'ta moê." Tada e s'tarac hv(a)lu b(og)u v'zdal'i rekal' e fratru: , Sada vim da e b(og) pokoru t'vôu priel. Naiprvo zamirai i budi skrban'i čuvai se prehineniê!” I reče fratar: „Od sada tebe ne ostavim otče do s'mrti.” 


\section{Disipul B}

Na to čt(e) se v'Ž(i)vlen'i s(ve)tih'o(ta)c

Niki frat(a)r imel' e sab'lazan' od žen'. I videl' e niku h'cerer popa poganskoga i namural'se s va nû i rekal'e ocu: „Dai mi t'voû h'cer za ženu.” Odgovoril' mu e: „Dati e neĉu dati dokli ne opitam b(og)a moga." I šal'e $k$ d'êv'lu i rekal'e': „Niki fratar oĉe v'zeti mô̂ h'cer za ženu, oĉu li mu û dati?” Odgov(o)r(i)l'e dêv(a)l: „Ako se od'vrže s'voga b(og)a i h(rstên) a i da poide van iz' reda, dai mu $\hat{u}$." I povidal $/ 3 \mathrm{a} /$ e to fratru. A on se e obeĉl da oĉe to vse učiniti i tudie mu e iz'letil d(u)h s(ve)ti iz' ust' k(a)ko golub. A pop'e šal'k' dêvlu i povedal mu e da oce frat(a)r na to pris'tati. I rekal' e dêv(a)l: „Ne dai mu e ere oĉe ni odaš(a)l' b(og) negov' od nega." I s'lišeĉi to frat(a)r i v'zdišuci i pomis'lil' e v' sebi: „,Kada mi e toliko dobro b(og) moi pokazal'buduĉi ê nes'riĉn'ni nega zataêl', i h(rstên)e $i$ red tr' mi oĉe pomaga, zač od nega grem.' I pošal' e v' pustinû k' nikomu dobru s'tarcu i to mu e povidal' komu s'tarac r(e)če da ima pos'titi .v.(=3) n(e)$d(\hat{e}) l e$ (nedile) ,a ê oĉu b(og)a moliti za te." I kada s'vrši prvu n(e)d(ê)lû opita ga s'tarac: „, Ako bi ča videl?” Rekal' e frat(a)r: ,Videl sam goluba u visini n(e)b(e)skoi letaûci nad manu.” R(e)če mu s'tarac': „Pokori se i moli b(og)a!" I kada isplni drugu n(e)d(ê)lû, pital' e starac: „Ako bi ča videl?” Rekal' e fr(a)t(a)r: „Videl sam goluba pri gl(a)vi moei." I isplniv'ši .v.(=3) n(e)d(ê)lû pital'je starac': „Ako bi oce videl'?” Rekal' e fr(a)t(a)r: „Priletilje goluba pri sebi, i otihi ga eti $i$ uide me /3b/va us'ta." Tada e s'tarac poznal'da mu e b(og) pros'til i priel pokoru negovu. I rekal mu e: „Od sada budi skrban'i dai hv(a)lu b(og)u i ne sagriši!” I r(e)če fr(a)t(a)r: „Od sada neĉu tebe os'taviti ot'če do semrti moe.”

IV. O sinu poganskog popa koji promatra kako đavao kažanjava svoje sluge

U latinskoj zbirci nalazi se na kraju 40. propovijedi Dominica I. Quadragesima (De tentationibus bonorum hominum) iz ciklusa de tempore (Herolt 1603: 152). Iz te je latinske propovijedi ovaj egzempl unesen u glagoljsku propovijed $N(e)$ $d(\hat{e}) l e . v .(=3)$ po Petikosteh'. Utvrđeno je kako je riječ o anegdoti unesenoj iz Pel. V ${ }_{39}$ (PL 73, col. 885-886) koja u Pelagijevu 5. poglavlju De fornicatione slijedi nakon anegdote $O$ redovniku koji se htio oženiti kćerju poganskoga popa. U Žićima svetih otaca nalazimo je kao 39./152. tekst pod nazivom Ot časa muža pravadnoga (Malić 1997: 67; 164-166). Pojavljuje se u Disipulima A (76ab), B (58bc) i $D(53 \mathrm{r})$. 


\section{Disipul A}

Na to čte se eks(e)m(pl) v Ž(i)vlen'i otac'.

Bil' e niki žakan' mal's(i)n' popa idol'skoga i sidil' e v' tem'pli kada e otac' negov'šal učiniti žrtvu idolom'. I šal' e za nim' otaino i videl' e sotonu sideĉi na pres'toli i sluge negove pred' nim' stoecii. I edan' od' nih' poklonil' mu se e govorecii: „Bil' sam' v' nikoi zem'li i v'zbudil' sam boi i proliênie krvi.” I r(e)če mu dêv(a)l: „V' koliki v'rimeni si to učinil,"” Odgov(o)ril' e: ,,V'.j.(=30) d'ni." I činil' ga e biti gov(o)r(e)ĉi: "Samo to si učinil'v toliki vrimeni?.” I prišal' e drugi i pok'lonil mu se e gov(o)r(e)ĉi: ",Bil' sam' v' mori i smutil' sam' more $i$ potopil' sam' plav' i s's lûdi." I r(e)če d'êv(a)l: „,V koliki vrimeni si to učinil'?” Odgov(o)ril e: ,V.i.(=20) dneh'." I toga e činil' biti. Pride treti i reče: „Učinil sam's'vaditi s'vate v' s'vad'bah' i pobili su se." I toga e činil biti. Pride č(e)trti i r(e)če: ,..k.(=40) l(e)t trudil' sam' se okolo nikoga redov'nika i ovu noĉ činil sam ga sagrišiti /76b/ bludom' s' niku ženu." I tada e d'êv(a)l v'stal' i kušnul' ga e. I iznam'ši k'runu svoû postavil' mu û e na gl(a)vu i posadil' ga e poli sebe. I to vidiv'ši žakan i rekal'e v' sebi da e velika čis'tota redovnič'ka i učinil se e redovnik' dobar.

\section{Disipul B}

Na to čt(e) se v Životi otac' da niki frat(a)r mlad' bil' e v' tem'pli, i kada e pop' idol'ski šal' učiniti žrtvu idolom' ta e šal' otai za nim'. I videl' e sotonu sideĉi na pristolu i nega hrabarstvo pred nim. I niki od knezov' negovih' poklonil mu se e i rekal mu e d'êv(a)l: „Kadi si bil?” Odgov(o)ril e: „Bil' sam' meû lûdi $i$ činil sam' svadu i proliê'ne krvi." Rekal mu e d'êv(a)l: „To si malo učinil'." Pride drugi i r(e)če mu: „Kadi si bil?” Odgov(o)ri: „Bil sam' na mori, i učin' sam fortunu i potopil sam lûdi i s'plavu.” Tomu r(e)če: "Ti si dobro učinil'." Pride treti i poveda: „Bil sam v' svadbah' i činil sam' kare i svati su se pobili.” I tomu r(e)če: ,I ti si dobro učinil'.”/58c/ Pride č(e)trti gov(o)r(e)ćci: ,..k.(=40) let trudil sam'se okolu nikoga fratra i ovu noĉ' sam' ga obladal', i činil' sam' ga sagrišiti s'ženu pl'teno." Tada e d'êv(a)l s'tal i kušn(u)l' ga e iz'nam'ši krunu iz gl(a)ve svoe pos't(a)v(i)l' mu e na gl(a)vu i činil' ga e poli sebe ses'ti gov(o)r(e)cî: „,Ti si naibole hodil ki si tu dušu dobil'." 


\section{O čovjeku koji se sramio vražjeg iskušenja}

Egzempl se pojavljuje na kraju 29. propovijedi $N($ e)d(ê)le.v. (=3) po okt(a)vi Ef(i)f(a)nie (lat. Dominica III. post octavae Epiphaniae, De tentationibus) (Herolt 1603: 113-114). Utvrđeno je da se nalazi na dvama mjestima u Verba seniorum: Ruf. 57 (PL 73, col. 769) i Pasch. I (PL 73, col. 1027). Pojavljuje se u Disipulima $A$ (42bc), $B(19 \mathrm{~d})$ i $D(19 \mathrm{v})$.

\section{Disipul A}

Eks(empl) čte se v' Ž(i)vl(e)n’i s(ve)tih' otac' v' kn(i)g(a)h .b.(=2) k(a)p(itu)l .l.v.(=53) da niki is'kušaše se od' d(u)ha hudeĉega i sramoval' se e to povidati. I kadi e videl stare lûdi k' nim' e šal'. I videl' e to niki star opat' $i$ rekal' mu e: „,Nu, s(i)nu, ti vele krat' prihaêš' k' meni skrban' $i$ opet' odhâ̂š' žalos'tan, povii mi ča e tebi.” A on' e rekal: „D'êval huleĉi mene ten'ta, to sam' se sramoval povidati." I rekal /42c/ mu e s'tarac': „Ne žalui se, sinu. Kada ti pride takovo smuĉenie i reci: , $\hat{E}$ uz'rok nisam, tvoega huleniê v'rhu tebe budi, sotono, ere toga duša moê neĉe. A ki godi uz'rok duša neĉe, ta ne more d'lgo prebivati'." I tako ta m'ladac' z'drav' bi učinen i šal e t'ê.

\section{Disipul D}

Naiposlidni zamiri eksempal. Čte se v Životi s(ve)tih' otac' da niki is'kušaše se od duha zaloga i sramoval se e to povidati. I kadi e dobre ludi slišal i stare $k$ nim e šal i rekal mu e niki star redovnik': „Nu, sinu, ti vele krat prihodiš $k$ meni imiûci mišleniê i opet greš tiê nesuĉi e s sobu, povii mi ča ti e.” A on reče: „Zali duh me tenta." I k(a)ko mu e povidal lagle mu e bilo. I rekal mu e starac: „Ne boi se, sinu. Znamenu se i reci: ,Ê uzrok nimam tvoga tentanê, sotono, ni duša moê. A ki uzrok duša neĉe, ne more ga premoĉi'." I tudie odašal ĵe zdrav.

\section{Zaključak}

Ovaj je rad potvrdio kako su zbirke propovijedi vrlo zahvalno vrelo kad je riječ o istraživanju korpusa Vitae Patrum u hrvatskoj srednjovjekovnoj književnosti. Naime, osim Žića svetih otaca i Dubrovačkoga legendarija, svi ostali tekstovi 
potekli iz Vitae Patrum pojavljuju se najčešće kao zasebni tekstovi u zbornicima, liturgijskim knjigama te u propovjednim zbirkama koje najčešće sadržavaju manje skupine egzempla. Utvrđeno je kako se u Disipulima pojavljuju prijevodi četiriju egzempla iz Verba seniorum te jedan egzempl iz tekstova Historia monachorum i Historia Lausiaca. S obzirom na to da se tekstovi pustinjskih otaca ovdje pojavljuju kao egzempli, istraživanje se provodilo uzimajući u obzir zakonitosti propovjednoga žanra, ali i odnos između monaške i dominikanske duhovnosti. Pokazalo se kako prevodilačka i prepisivačka rješenja nisu uvijek nužno odraz ekonomizacije izraza i naglašavanja didaktičnosti narativa, nego i posljedica prilagođavanja monaških motiva kontekstu kasnoga srednjovjekovlja. Usporedba Disipula s latinskim predloškom pokazala je kako egzempli u pojedinim prijepisima prenose poruku drukčiju od one koju zatječemo u tekstu iz monaškoga vremena. Pojava skromnih amplifikacijskih postupaka označava utjecaj kasnosrednjovjekovnoga konteksta na prevođenje/prepisivanje teksta iz Vitae Patrum. Različiti oblici kontrakcije teksta uglavnom se odnose na kraćenja dijaloga, sažimanja nekoliko odgovora i pitanja u jedan iskaz te na izostavljanje pojedinih opisa. Sažeti dijelovi egzempla nastoje se stilski obilježiti na sintaktičkoj i leksičkoj razini, npr. oblikovanjem sintaktičkih paralelizama, zamjenjivanjem kraćih odlomaka rečenicama u kojima se pojavljuju posuđenice i sl. Utvrđeno je kako u glagoljskim Disipulima nalazimo dva (uvjetno rečeno tri) egzempla paralelna onima iz Žića svetih otaca: dva su nastala prema istim anegdotama iz Pelagijeva dijela zbirke Verba seniorum, dok treći s anegdotom iz Žića dijeli samo uvodni motiv.

Analiza jezičnih značajka pokazala je kako u egzemplima nalazimo primjere čakavske jake vokalnosti. Pronađeno je nekoliko značajka koje se ponajviše povezuju sa sjevernom čakavštinom (imperfektni nastavak - hi, niječni oblik nete pomoćnoga glagola htiti, nastavak - $u$ za I jd. ž. r.). Refleks je jata ikavsko-ekavski, a učestala pojava apostrofa vjerojatno je odraz pisarske tradicije. Potvrđeni su primjeri starijih (hrvatskocrkvenoslavenskih) gramatičkih oblika, no vrlo često nalazimo paralelnu uporabu novijih čakavskih oblika. Poznavanje starijih glagoljskih tekstova, koje se najjasnije održava u jezičnome izboru, odražava se i na grafijskoj razini uporabom ligatura karakterističnih za liturgijske knjige (npr. ligaturom spojen izraz $n n \widetilde{b} o$, odnosno $n(a) n(e) b o$ ). Pojava nekoliko leksičkih crkvenoslavizama stilski je obilježena s obzirom na to da se na paralelnim mjestima u drugim prijepisima pojavljuju noviji leksemi (hrabarstvo prema knezov, 
otai prema otaino). Pronalazak ranih potvrda nekoliko riječi (vancati, flaščica, splav), uz već utvrđene primjere ranih kajkavizama koji su upravo u Disipulima utvrđeni u istraživanju iz 2016. godine, jasan je pokazatelj vrijednosti zbirka propovijedi kada govorimo o proučavanju hrvatskoga jezika 16. stoljeća.

\section{Literatura:}

Badurina-STiPČević, Vesna. 1992-1993. Hrvatskoglagoljska Legenda o sv. Pavlu Pustinjaku. Croatica XXIII-XXIV/37-39. 51-59.

Badurina-StipČEvić, Vesna. 2004. Legenda o sv. Hilarionu Opatu u hrvatskoglagoljskim brevijarima. Slovo 52-53. 27-40.

Badurina-StipČEvić, Vesna. 2008. Translacija sv. Pavla Pustinjaka u hrvatskoglagoljskom II. novljanskom brevijaru iz 1495. godine. Slovo 58. 285-312.

BAdurina-StipČEvić, VeSNA. 2011. Legenda o svetom Antunu opatu u hrvatskoglagoljskoj književnosti. Az grišni diak Branko pridivkom Fučić. Radovi međunarodnoga znanstvenog skupa o životu i djelu akademika Branka Fučića (1920. - 1999.). Ur. Galović, Tomislav. HAZU - Institut za povijest umjetnosti - Katolički bogoslovni fakultet Sveučilišta u Zagrebu - Staroslavenski institut - Sveučilišna knjižnica Rijeka - Općina Malinska-Dubašnica. Malinska - Rijeka - Zagreb. 467-474.

Bertrand, PAsCal. 2006. Shaping authority and identity: Saint Antony and his followers in early monastic texts. Text and Identities in the Early Middle Ages. Ur. Corradini, Richard. Denkschriften der Österreichischen Akademie der Wissenschaften, Philosophisch-Historische Klasse, Bd. 344. Forschungen zür Geschichte des Mittelalters, Bd. 12. Verlag der Österreichischen Akademie der Wissenschaften. Wien. 179-189.

Bodrožić, Ivan. 2015. O Bogu posvećenom životu u patristici. Prikaz povijesnoga razvoja i duhovnosti. Diacovensia 23/4. 425-440.

Boureau, Alain. 1987. Vitae fratrum, Vitae patrum. L'Ordre dominicain et le modèle des Pères du désert au XIIIe siècle. Mélanges de l'Ecole française de Rome. MoyenÂge. Temps modernes 99/1. 79-100.

Bremond, Claude; Le Goff, Jacques; Schmitt, Jean-Claude. 1996. L'Exemplum. Typologie des sources du Moyen Âge occidental, fasc. 40. Brepols. Turnhout.

BudJA, JURICA. 2018. Napomene o leksemu splav. Rasprave Instituta za hrvatski jezik $i$ jezikoslovlje 44/1. 89-111. doi.org/10.31724/rihjj.44.1.3.

Butler, Dom Cuthbert. 1898. The Lausiac History of Palladius. A Critical Discussion together with notes on early Egyptian Monachism. Cambridge University Press. Cambridge.

Crane, Thomas Frederick. 1890. The exempla or illustrative stories from the Sermones 
vulgares of Jacques de Vitry. Publications of the Folklore Society London. London.

Dahmus, John. 1986. Late Medieval Preachers and Lay Perfection: the Case of Johannes Herolt, OP. Medieval perspectives 1. 122-134.

Damuanović, StJePan. 2008. Jezik hrvatskih glagoljaša. Matica hrvatska. Zagreb.

Damjanović, Stjepan. 2014. Novi filološki prinosi. Matica hrvatska. Zagreb.

Delarue, Dominic E. 2018. Concepts of Solitude in Jacobus de Voragine's Legenda aurea. Solitudo: Spaces, Places, and Times of Solitude in Late Medieval and Early Modern Cultures. Ur. Enenkel, Karl A. E.; Göttler, Christine. Brill. 121-139. doi.org/10.1163/9789004367432_005.

Delcorno, Carlo. 1991. Le »Vitae Patrum« nella letteratura religiosa medievale (secc. XIII-XV). Lettere Italiane 43/2. 187-207.

Di Sciacca, Claudia. 2014. "Concupita, quaesita, ac petita solutidines secreta": the desert ideal in Bedes prose Vita S. Cuthberti and Aelfric's life of St Cuthbert. Hagiography in Anglo-Saxon England: Adopting and adapting Saint's lives into Old English prose (c. 950-1150). Ur. Lazzari, Loredana; Lendinara, Patrizia; Di Sciacca, Claudia. Fédération Internationale des Instituts d'Études Médiévales - Textes et Études du Moyen Âge. Barcelona - Madrid. 121-181. doi.org/10.1484/M.TEMA-EB.5.107199.

DÜRrigl, MARIJA-ANA. 2010. (De)kompozicija srednjovjekovnih nabožnih tekstova sermones morales u »Ljubljanskom zborniku«. Umjetnost riječi 54/1-2. 1-22.

GALIĆ, Josip. 2018. Fonološke osobitosti Zbornika u Berčićevoj zbirci br. 5 i Fatevićeva zbornika duhovnoga štiva. Slovo 68. 99-169. doi.org/10.31745/s.68.5.

Greer, Rowan A. 1989. The Fear of Freedom: A Study of Miracles in the Roman Imperial Church. Pennsylvania State University Press. Pennsylvania.

Harmless, William S. J. 2004. Desert Christians: An Introduction to the Literature of Early Monasticism. Oxford University Press. Oxford. doi.org/10.1093/0195162234.001 .0001 .

Hercigonja, Eduard. 1974. Kajkavski elementi u jeziku glagoljske književnosti 15. i 16. stoljeća (prilog istraživanju kontinuiteta hrvatskoga književnog jezika). Croatica 5. 169-245.

Hercigonja, EduARd. 1975. Povijest hrvatske književnosti: srednjovjekovna književnost. Knj. 2. Liber - Mladost. Zagreb.

Hercigonja, EduARd. 2004. Na temeljima hrvatske književne kulture. Matica hrvatska. Zagreb.

Hermand, Xavier. 1995. Les Vitae Patrum dans le Promptuarium exemplorum de Jean Herolt (†1468). Revue d'histoire ecclésiastique 90. 5-48.

Herolt, Johannes. 1603. Sermones Discipuli de tempore et de sanctis cum Promptuario exemplorum ac miraculis Beatae Mariae Virginis. Apud Petrum Mariam Bertanum. 
Venetiis.

IvŠIĆ, STJEPAn. 1939. Nekoliko napomena uz starohrvatski tekst „Žića sv. Otaca”. Starine JAZU 40. 225-251.

Jotischky, Andrew. 2002. The Carmelites and Antiquity: Mendicants and their Pasts in the Middle Ages. Oxford University Press. Oxford.

Kapetanović, Amir. 2004. Tekstološka obrada i jezična analiza Berčićeva glagoljskoga fragmenta (I/27) iz XV. stoljeća. Rasprave Instituta za hrvatski jezik i jezikoslovlje 30. 85-96.

Kapetanović, Amir. 2011. Čakavski hrvatski književni jezik. Povijest hrvatskoga jezika 2. Ur. Bičanić, Ante; Katičić, Radoslav; Lisac, Josip. Croatica. Zagreb. 77-123.

KuzMić, Boris. 2002. Jezična obilježja Senjskog korizmenjaka. Rasprave Instituta za hrvatski jezik i jezikoslovlje 28. 87-101.

Le Goff, JACQues. 1998. Civilizacija srednjovjekovnog zapada. Golden Marketing. Zagreb.

LuČIĆ, VIDA. 2009. Prijevodni obrasci, konceptualizacija i značenje leksema hrvatske crkvenoslavenske osnove smêr- u nebiblijskim tekstovima. Slovo 59. 189-230.

Malić, DragiCA. 1996. Atribut i apozicija u Žićima svetih otaca. Rasprave Instituta za hrvatski jezik i jezikoslovlje 22. 65-109.

Malić, DragicA. 1997. Žića svetih otaca. Hrvatska srednjovjekovna proza. Matica hrvatska - Institut za hrvatski jezik i jezikoslovlje. Zagreb.

Malić, Dragica. 2002. Na izvorima hrvatskoga jezika. Matica hrvatska. Zagreb.

Moro, DušAn. 2004. Monaštvo - znak i poticaj jedinstvu crkve. Služba Božja 44/1. $35-71$.

Novaković, Darko. 1986. Marulićeva Davidijada kao priča. Latina et Graeca 28/1. $5-16$.

Petrović, Ivanka. 1972. Bogorodičina čudesa u Ivančićevu zborniku, hrvatskoglagoljskom spomeniku 14./15. st. Radovi Staroslavenskog instituta 7. 123-210.

Petrović, Ivanka. 1977. Marijini mirakuli u hrvatskim glagoljskim zbirkama i njihovi europski izvori. Radovi Staroslavenskog instituta 8. 3-243.

Petrović, IvankA. 1984. Hagiografsko-legendarna književnost hrvatskog srednjovjekovlja i senjski »Marijini mirakuli«. Izvori, žanrovske, tematske i tipološke karakteristike. Slovo 34. 181-201.

Petrović, Ivanka. 1990. Hrvatski srednjovjekovni legendariji. Croatica - Slavica - Indoeuropaea (posvećeno R. Katičiću u povodu 60. obljetnice života). Wiener Slavistisches Jahrbuch VIII. Verlag der Österreichischen Akademie der Wissenschaften. Wien. 181-192.

Petrović, Ivanka. 2005. Les »Vitae Patrum« dans la littérature croate du Moyen Âge. 
"Scribere sanctorum gesta". Recueil d'études d'hagiographie médiévale offert à Guy Philippart. Ur. Renard, Étienne; Trigalet, Michel; Hermand, Xavier; Bertrand, Paul. Brepols. Turnhout. 283-307.

Philippart, Guy. 1974. Vitae Patrum Trois travaux récents sur d'anciennes traductions latines. Analecta Bollandiana 92/3-4. 353-365.

Premuda, Vinko. 1939. Starohrvatski latinički rukopis »Žića sv. otaca«. Prijevod izabranog štiva iz djela sv. Jeronima »Vitae sanctorum Patrum«. Starine JAZU 40. 111-218.

Radošević, Andrea. 2016a. Kajkavizmi u hrvatskome prijevodu Disipula Johannesa Herolta († 1468.). Rasprave Instituta za hrvatski jezik i jezikoslovlje 42/1. 246-266.

RadošEvić, Andrea. 2016b. Motiv pro(daje) duše vragu u glagoljskim egzemplima. XLII Меѓународна научна конференција на XLVIII меѓународен семинар за македонски јазик, литература и култура. Ur. Велева, Славица. Универзитет св. Кирил и Методиј. Скопје. 203-221. [RADošEvić, ANDREA. 2016b. Motiv pro(daje) duše vragu u glagoljskim egzemplima. XLII Meǵunarodna naučna konferencija na XLVIII meǵunaroden seminar za makedonski jazik, literatura i kultura. Ur. Veleva, Slavica. Univerzitet sv. Kiril i Metodij. Skopje. 203-221.]

Radošević, Andrea. 2017. Croatian Translation of Biblical Passages in Medieval Performative Texts. Translating Christianity. Studies in Church History 53. Ur. Ditchfield, Simon; Methuen, Charlotte; Spicer; Andrew. Cambridge University Press. 223-241. doi.org/10.1017/stc.2016.14.

Radošević, Andrea. 2019. Egzempli u Divkovićevim Besjedama i glagoljskim Disipulima prema djelu Sermones Discipuli Johannesa Herolta. Colloquia franciscana I. Zbornik fra Marka Karamatića. Ur. Grmača, Dolores. Kulturno-povijesni institut Bosne Srebrene. Sarajevo. 87-108.

Reinhart, Johannes. 2014. Sintaksa. Hrvatski crkvenoslavenski jezik. Ur. Mihaljević, Milan. Hrvatska sveučilišna naklada - Staroslavenski institut. Zagreb. 305-364.

Salisbury, Joyce E. 2010. When Sex Stopped Being a Social Disease. Sex and the Desert Fathers and Mothers. Medieval Sexuality. A Casebook. Ur. Harper, April; Proctor, Caroline. Routledge. New York. 47-58.

Sheridan, Mark. 2015. John of Lycopolis. Christianity and Monasticism in Middle Egypt. Ur. Gabra, Gawdat; Takla, Hany. The American University in Cairo Press. Cairo. $123-132$.

SkoK, Petar. 1971-1974. Etimologijski rječnik hrvatskoga ili srpskoga jezika I-IV. JAZU. Zagreb.

ŠTEFAniĆ, VJeKoslav. 1960. Glagoljski rukopisi otoka Krka. JAZU. Zagreb.

ŠTEFANIĆ, VJeKosLav. 1969. Glagoljski rukopisi Jugoslavenske akademije, I dio. JAZU. Zagreb. 
ŠTrkalu Despot, Kristina. 2005. Dosad neobjavljena hrvatska verzija Legende o svetom Eustahiju. Rasprave Instituta za hrvatski jezik i jezikoslovlje 31. 355-383.

Štrkalu DesPot, Kristina. 2010. Jezične i književnopovijesne značajke starohrvatskih pjesama u Picićevoj pjesmarici iz 1471. Colloquia Maruliana 19. 31-53.

TAtarin, Milovan. 2003. Bludnica i svetica: starohrvatska legenda o Mariji Egipćanki. Naklada Ljevak. Zagreb.

Van Doom-Harder, Pieternella. 1995. Contemporary Coptic Nuns. University of South Carolina Press. Columbia.

Vince, Jasna. 2014. Imenice. Hrvatski crkvenoslavenski jezik. Ur. Mihaljević, Milan. Hrvatska sveučilišna naklada - Staroslavenski institut. Zagreb. 91-132.

Welter, JeAn-ThiÉBAut. 1973. L'Exemplum dans la littérature religieuse et didactique du Moyen Âge. Pretisak prvoga izdanja iz 1927. godine. Slatkine reprints. Geneve.

Winfried, Rudolf. 2014. The selection and compilation of the Verba seniorum in Worchester, Cathedral Library, f. 48. Hagiography in Anglo-Saxon England: Adopting and adapting Saint's lives into Old English prose (c. 950 - 1150). Ur. Lazzari, Loredana; Lendinara, Patrizia; Di Sciacca, Claudia. Fédération Internationale des Instituts d'Études Médiévales - Textes et Études du Moyen Âge. Barcelona - Madrid. 183-227. doi.org/10.1484/M.TEMA-EB.4.01017.

Zaradija Kiš, AntoniJa. 2008. Egzempli u senjskom Korizmenjaku. Senjski zbornik 35. 55-90.

ZaradiJa KIš, AntoniJa. 2012. Nezahvalni sin ili Čovjek s krastačom na licu. Narodna umjetnost 49/2. 115-138.

Zlatar, Andrea. 2001. Transformacije hagiografske matrice u Marulićevu djelu De institutione bene beateque vivendi per exempla sanctorum. Colloquia Maruliana 10. $77-85$.

Zlatar, Andrea. 2002. Transformacija biblijskoga predloška u Marulićevoj Juditi. Colloquia Maruliana 11. 47-55.

\section{Popis rječnika i izvora:}

$\mathrm{ARj}=$ Rječnik hrvatskoga ili srpskoga jezika I-XXIII. 1880.-1976. JAZU. Zagreb.

$\mathrm{A}=\operatorname{Disipul} A$, sredina 16. st., Arhiv Krčke biskupije.

$\mathrm{B}=$ Disipul B, 1558., Arhiv HAZU, sign. VIII 126.

$\mathrm{C}=$ Disipul C, 1541., Arhiv HAZU, sign. IV a 95.

D = Disipul D, 1600., Arhiv HAZU, sign. III b 13 (Kuk. 5).

$\mathrm{HL}=$ De Vitis partum liber octavus, sive Historia Lausiaca, auctore Palladio, Helenopoleos episcopo, interprete Gentiano Herveto, Parisiis 1849, PL 73, col. 1091-121. 
$\mathrm{HM}=$ Historia monachorum seu Liber de Vitis partum, auctore Rufino Aquileiensi presbytero. PL 21. Ur. J.-P. Migne, Parisiis 1849, col. 387-465.

Pasch. = De vitis patrum liber septimus, sive Verba seniorum, auctore graeco incerto, interprete Paschasio S. R. E. diacono. PL 73. Ur. J.-P. Migne, Parisiis, 1849, col. 1025-1062.

Pel. = De vitis patrum liber quintus, sive Verba seniorum, auctore graeco incerto, interprete Pelagio S. R. E. diacono. PL 73. Ur. J.-P. Migne, Parisiis, 1849, col. 851-992.

Ruf. = De vitis partum liber tertius, sive Verba seniorum, auctore probabili Ruffino Aquileiensi presbytero. PL 73. Ur. J.-P. Migne, Parisiis, 1849, col. 739-852.

\section{Vitae Patrum in the Exemplas of the Glagolitic Sermon Collection Disipuli from the 16th Century}

\section{Abstract}

In this paper the author analyses texts from the Vitae Patrum that appear in the form of exemplum in the four Glagolitic manuscripts from the $16^{\text {th }}$ century that are known as Disipuli. The first part of the paper focuses on the analysis of the Dominican's use of the monastic anecdotes, especially regarding the Latin sermon collection Sermones Discipuli according to which Croatian translation was created. The relationship towards monastic themes in four Glagolitic manuscripts is further compared. In the previous medievistic studies (Hermand 1995) only the sources of the exempla from Herolt's Promptuarium Exemplorum were identified. The sources of several Latin exempla from two Herolt's cycles (sermones de tempore, sermones de sanctis) are here determined for the first time. The research has shown that four exempla were compiled from Verba seniorum and one exemplum is borrowed from the anecdote of John Lycopolis that is written in Historia Lausiaca and Historia monachorum.

In the second part of the paper, the linguistic and stylistic characteristics of the exempla are described. The aim of the research is to expand the knowledge about the reception of the Vitae Patrum in the Croatian medieval literature but also about the corpus of Croatian late medieval short narratives. Namely, one part of the Croatian medieval corpus of Vitae Patrum could be substantially completed by exploring sermon collections because they usually contain at least several monastic anecdotes. At the end of the paper, the transliteration of all five exempla is published for the first time.

Ključne riječi: Vitae patrum, egzempl, Sermones Disipuli, starohrvatski (čakavski) jezik, 16. stoljeće, glagoljski rukopis

Keywords: Vitae Patrum, exemplum, Sermones Discipuli, Old Croatian (Chakavian) language, 16 th century, glagolitic manuscript 